Supporting Information

\title{
A Disulfide-Reduction Triggering Spontaneous Photoblinking Cy5 Probe for Nanoscopic Imaging of Mitochondrial Dynamics in Live Cells
}

Wen Li, Wenhui Pan, Meina Huang, Zhigang Yang, * Ying He, Wei Zhang, Jianguo Zhang, Zhenyu Gu, Dan, Zhang, Wei Yan, and Junle Qu*

Center for Biomedical Photonics \& College of Physics and Optoelectronic Engineering, Shenzhen University, Shenzhen 518060, China

E-mail: zhgyang@szu.edu.cn; jlqu@szu.edu.cn

\section{Contents}

Supplementary Videos

Supplementary Table 1

Supplementary Scheme 1

Supplementary Figure 1

Supplementary Figure 2-4

Supplementary Figure 5-6

Supplementary Figure 7-8

Supplementary Figure 9-10

Supplementary Figure 11-12

\author{
page $\mathrm{S} 2$ \\ page $\mathrm{S} 3$ \\ page $\mathrm{S} 3$ \\ page $\mathrm{S} 3$ \\ page $\mathrm{S} 4$ \\ page S5 \\ page $\mathrm{S} 6$ \\ page $\mathrm{S} 7$ \\ page $\mathrm{S} 8$ \\ page $\mathrm{S} 9$ \\ page $S 10$ \\ page $\mathrm{S} 11$ \\ page S12-S15 \\ page $\mathrm{S} 15-18$ \\ page S19-S23 \\ page $\mathrm{S} 24$
}

Supplementary Figure 13-14

Supplementary Figure 15-16

Supplementary Figure 17-18

Experiment Section

Synthetic procedures

Structural Identifications(NMR data)

Reference 
Video S1-S5

\begin{tabular}{|c|c|c|c|}
\hline $\begin{array}{l}\text { Supplementary } \\
\text { videos }\end{array}$ & Description & Laser power & Other parameters \\
\hline $\begin{array}{l}\text { Supplementary } \\
\text { video S1 }\end{array}$ & $\begin{array}{l}\text { The photo-blinking } \\
\text { movie of Fluo-SH after } \\
\text { 200s illumination }\end{array}$ & $\begin{array}{l}0.4 \mathrm{~kW} / \mathrm{cm}^{2} \\
@ 656 \mathrm{~nm}\end{array}$ & $\begin{array}{l}\text { Image Size: } 89 \text { x } 89 \\
\text { Pixel Size: } 224.36 \mathrm{~nm} \\
\text { EMCCD Frequency: } 60 \mathrm{~Hz} \\
\text { NA of oil objective lens: } \\
1.45\end{array}$ \\
\hline $\begin{array}{l}\text { Supplementary } \\
\text { video S2 }\end{array}$ & $\begin{array}{l}\text { The comparison of } \\
\text { photoblinking duration } \\
\text { of Mito-SS in } \\
\text { mitochondria cultured } \\
\text { for } 10 \text { minutes and } 1 \\
\text { hour, respectively. }\end{array}$ & $\begin{array}{l}0.4 \mathrm{~kW} / \mathrm{cm}^{2} \\
@ 656 \mathrm{~nm}\end{array}$ & $\begin{array}{l}\text { I Image Size: } 256 \text { x } 128 \\
\text { Pixel Size: } 156 \mathrm{~nm} \\
\text { Frames Per Second of } \\
\text { EMCCD Frequency: } 120 \\
\text { Hz } \\
\text { NA of oil objective lens: } \\
1.45\end{array}$ \\
\hline $\begin{array}{l}\text { Supplementary } \\
\text { video S3 }\end{array}$ & $\begin{array}{l}\text { The raw data of } \\
\text { mitochondria with the } \\
\text { probe under different } \\
\text { laser power. }\end{array}$ & $656 \mathrm{~nm}$ & $\begin{array}{l}\text { EMCCD Frequency: } 60 \mathrm{~Hz} \\
\text { NA of oil objective lens: } \\
1.45\end{array}$ \\
\hline $\begin{array}{l}\text { Supplementary } \\
\text { video S4 }\end{array}$ & $\begin{array}{l}\text { Super-resolution } \\
\text { dynamics of the } \\
\text { mitochondrial tubulation } \\
\text { which was marked by } \\
\text { white arrow compared } \\
\text { with average images } \\
\text { whose duration is more } \\
\text { than } 3 \text { minutes. }\end{array}$ & $\begin{array}{c}0.05 \mathrm{~kW} / \mathrm{cm}^{2} \\
656 \mathrm{~nm}\end{array}$ & $\begin{array}{l}\text { Image Size: } 512 \text { x } 256 \\
\text { Pixel Size: } 27 \mathrm{~nm} \\
\text { EMCCD Frequency: } 60 \mathrm{~Hz} \\
\text { NA of oil objective lens: } \\
1.45 \\
\text { Temporal resolution: } 4 \mathrm{~s}\end{array}$ \\
\hline $\begin{array}{l}\text { Supplementary } \\
\text { video S5 }\end{array}$ & $\begin{array}{l}\text { Super-resolution } \\
\text { dynamics of the } \\
\text { mitochondrial fission } \\
\text { and tubulation which } \\
\text { was marked by white } \\
\text { arrow with average } \\
\text { images whose duration } \\
\text { is } 2 \text { minutes. }\end{array}$ & $\begin{array}{l}0.1 \mathrm{~kW} / \mathrm{cm}^{2} \\
@ 656 \mathrm{~nm}\end{array}$ & $\begin{array}{l}\text { Image Size: } 512 \text { x } 256 \\
\text { Pixel Size: } 40 \mathrm{~nm} \\
\text { EMCCD Frequency: } 120 \\
\text { Hz } \\
\text { NA of oil objective lens: } \\
1.45 \\
\text { Temporal resolution: } 2 \mathrm{~s}\end{array}$ \\
\hline
\end{tabular}


Table S1. Photoswitching properties of commerical dye of Alexa 647 and Fluo-SH.

\begin{tabular}{|c|c|c|c|c|}
\hline STORM Fluorophore & $\begin{array}{l}\text { Photons } \\
\text { per } \\
\text { Switching } \\
\text { Event }\end{array}$ & Duty Cycle & $\begin{array}{l}\text { Survival } \\
\text { Fraction }\end{array}$ & $\begin{array}{l}\text { Cycle } \\
\text { Number }\end{array}$ \\
\hline $\begin{array}{l}\text { Alexa } 647 \\
(140 \mathrm{mM} \\
\beta \mathrm{ME}+\mathrm{GLOX}) \\
0.8 \mathrm{~kW} \cdot \mathrm{cm}^{-2} \\
\text { Fluo-SH }\end{array}$ & 5202 & $0.0012(400-600 \mathrm{~s})$ & $\begin{array}{l}0.73 \text { after } \\
400 \mathrm{~s}\end{array}$ & 26 \\
\hline $\begin{array}{l}\text { Only PBS (pH=7.4) } \\
0.4 \text { kW.cm }{ }^{-2} \\
\text { Fluo-SH }\end{array}$ & 700 & $\begin{array}{l}0.0121(50-150 \mathrm{~s}) \\
0.0009(400-600 \mathrm{~s})\end{array}$ & $\begin{array}{l}0.75 \text { after } \\
400 \mathrm{~s}\end{array}$ & 30 \\
\hline $\begin{array}{l}\text { Only PBS }(\mathrm{pH}=7.4) \\
1.0 \mathrm{~kW} \cdot \mathrm{cm}^{-2}\end{array}$ & 1100 & $\begin{array}{l}0.0124(50-150 \mathrm{~s}) \\
0.0025(400-600 \mathrm{~s})\end{array}$ & $\begin{array}{l}0.7 \text { after } \\
400 \mathrm{~s}\end{array}$ & 44 \\
\hline
\end{tabular}

GLOX $=$ glucose oxidase, $\beta \mathrm{ME}=\beta$-mercaptoethanol, data of Alexa647 was from ref. 1

\section{Supplementary Figures}

a.

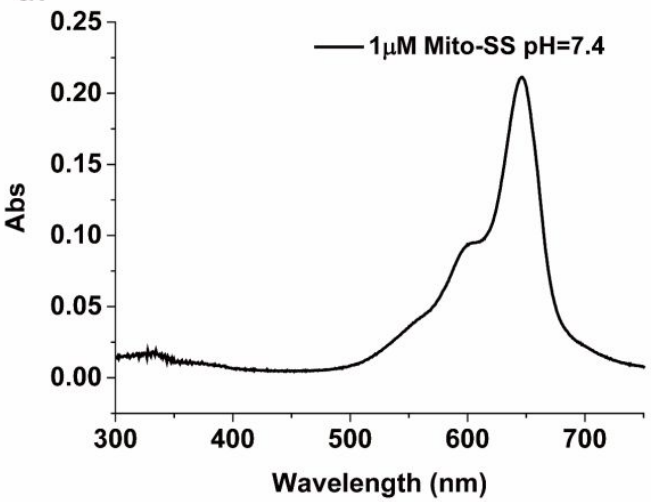

b.

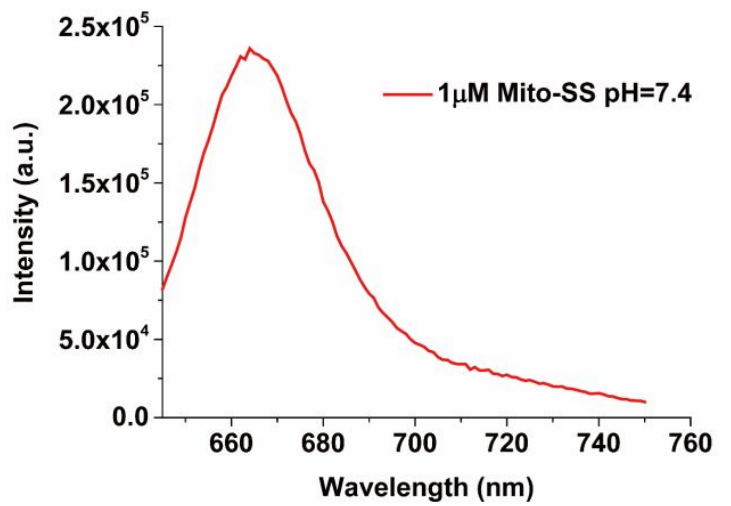

Figure S1. Absorption and emission spectrum (ex: $630 \mathrm{~nm}$ ) of $1 \mu \mathrm{M}$ Mito-SS in PBS (pH = 7.4). 

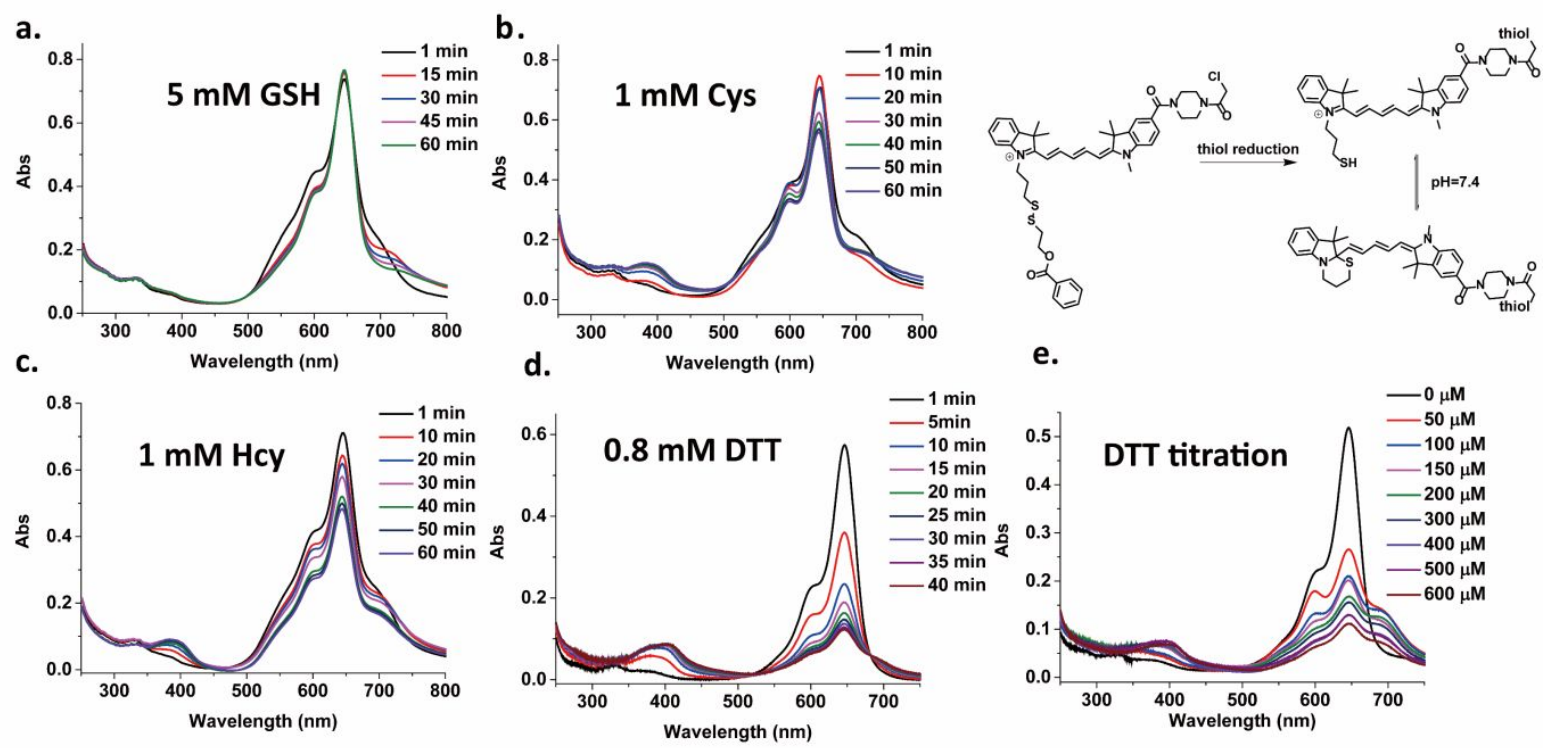

Figure S2. Absorption spectra of Mito-SS $(4 \mu \mathrm{M})$ in $1 \times \mathrm{PBS}(\mathrm{pH}=7.4)$ incubated with a) 5 mM GSH; b) $1 \mathrm{mM}$ Cys; c) $1 \mathrm{mM} \mathrm{Hcy}$; and d) $0.8 \mathrm{mM}$ DTT for different time; e) Absorption spectra of Mito-SS $(2.5 \mu \mathrm{M})$ in PBS $(\mathrm{pH}=7.4)$ incubated with different concentration of DTT for 40 minutes.

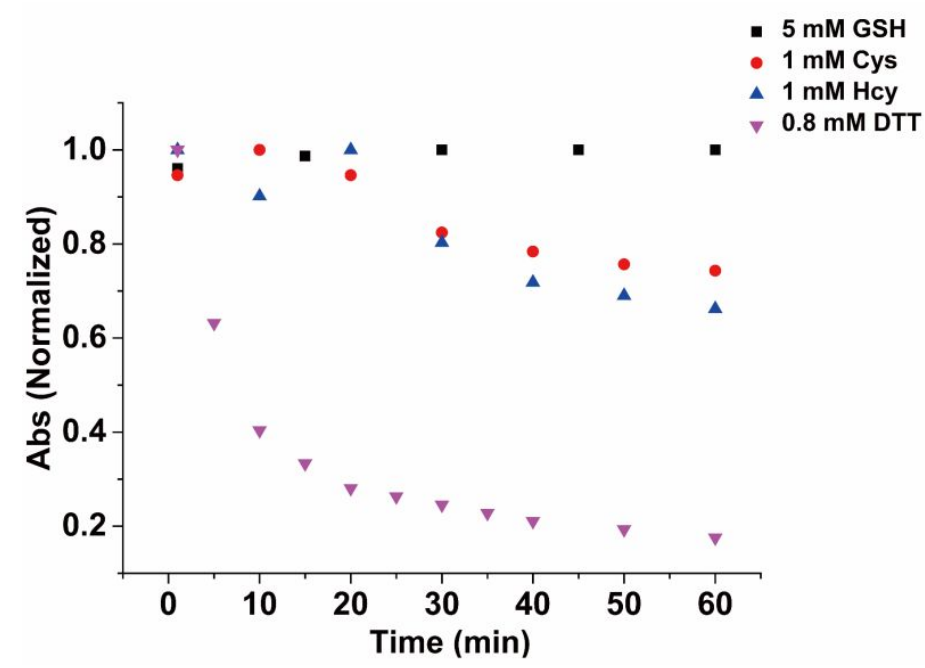

Figure S3 Kinetic absorption changes of Mito-SS $(5 \mu \mathrm{M})$ at $647 \mathrm{~nm}$ incubated with different thiols at $25{ }^{\circ} \mathrm{C}$ in PBS ( $\mathrm{pH}=7.4$ );

a.

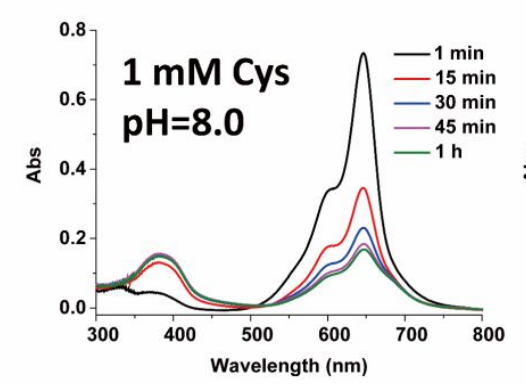

b.

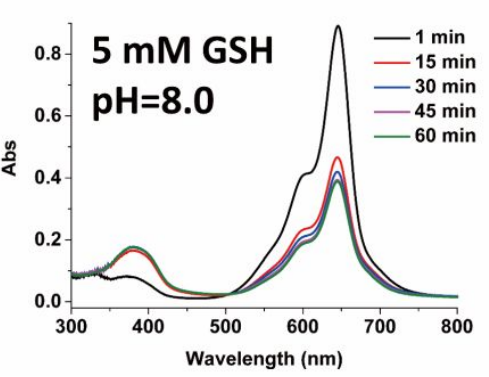

c.

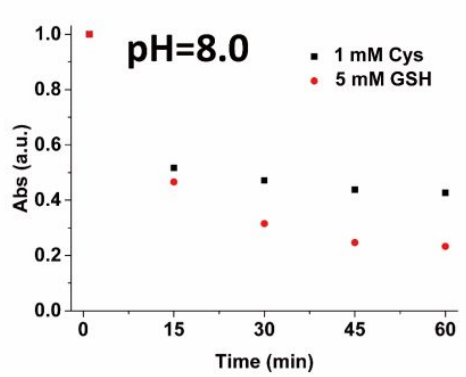

Figure S4. Absorption spectra of Mito-SS $(4 \mu \mathrm{M})$ in $0.1 \mathrm{M}$ PIPES aqueous solution (containing borax to adjust $\mathrm{pH}$ to 8.0 ) incubated with a) $1 \mathrm{mM}$ Cys; b) $5 \mathrm{mM} \mathrm{GSH}$ for different time. c) Kinetic absorption changes of Mito-SS at $647 \mathrm{~nm}$ treated with different thiols at $25{ }^{\circ} \mathrm{C}$ in $0.1 \mathrm{M}$ PIPES aqueous solution (containing borax to adjust $\mathrm{pH}$ to 8.0). 


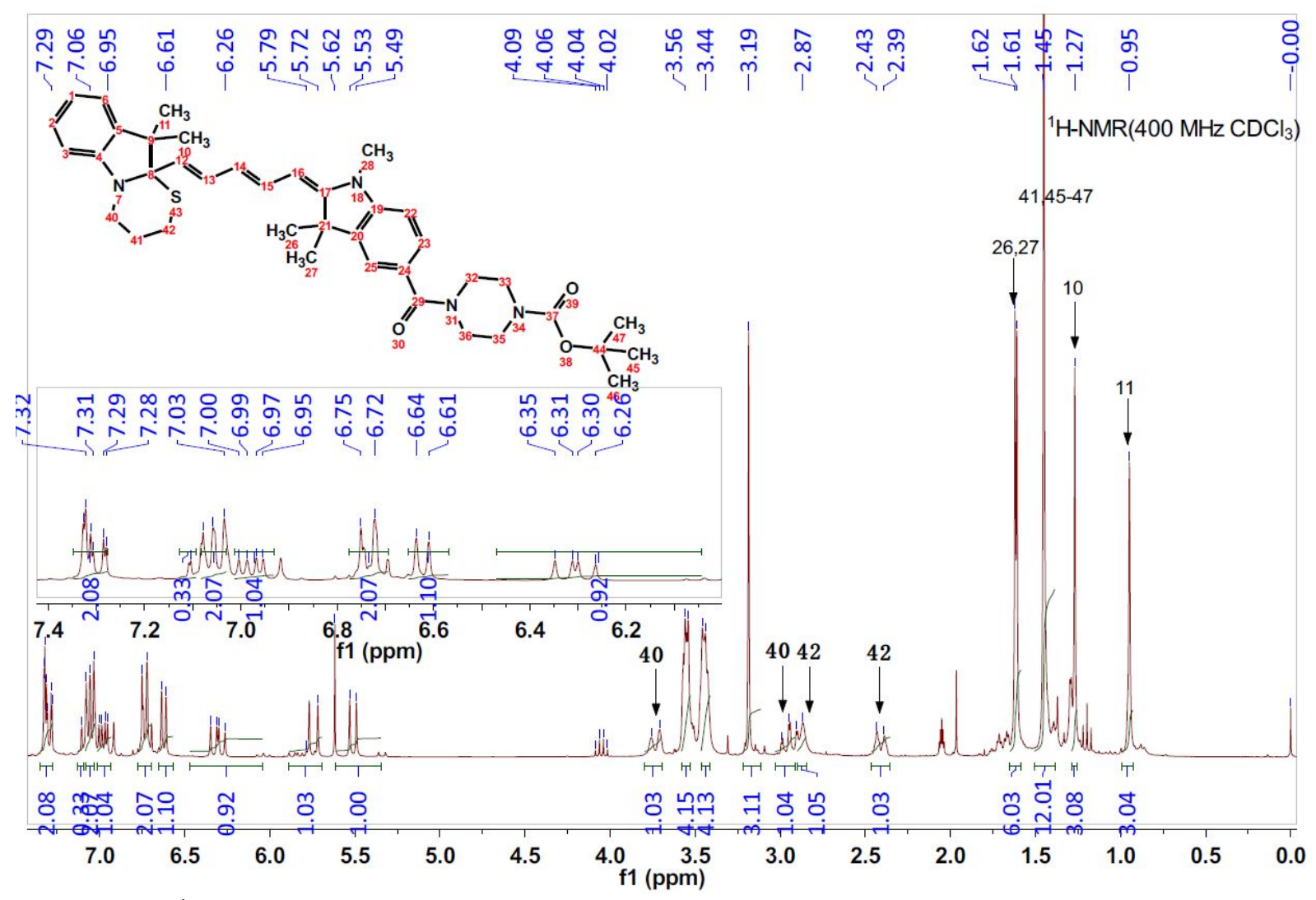

Figure S5. ${ }^{1} \mathrm{H}-\mathrm{NMR}\left(400 \mathrm{MHz} \mathrm{CDCl}_{3}\right.$ ) spectra of the ring-closed form of Fluo-SH in $\mathrm{CDCl}_{3}$ (The $\mathrm{H}$ belonging to the $\mathrm{C}(40,42,10,11)$ demonstrate different chemical shift due to the steric effect of the six-membered ring which is in accordance with reported literature) ${ }^{[2]}$

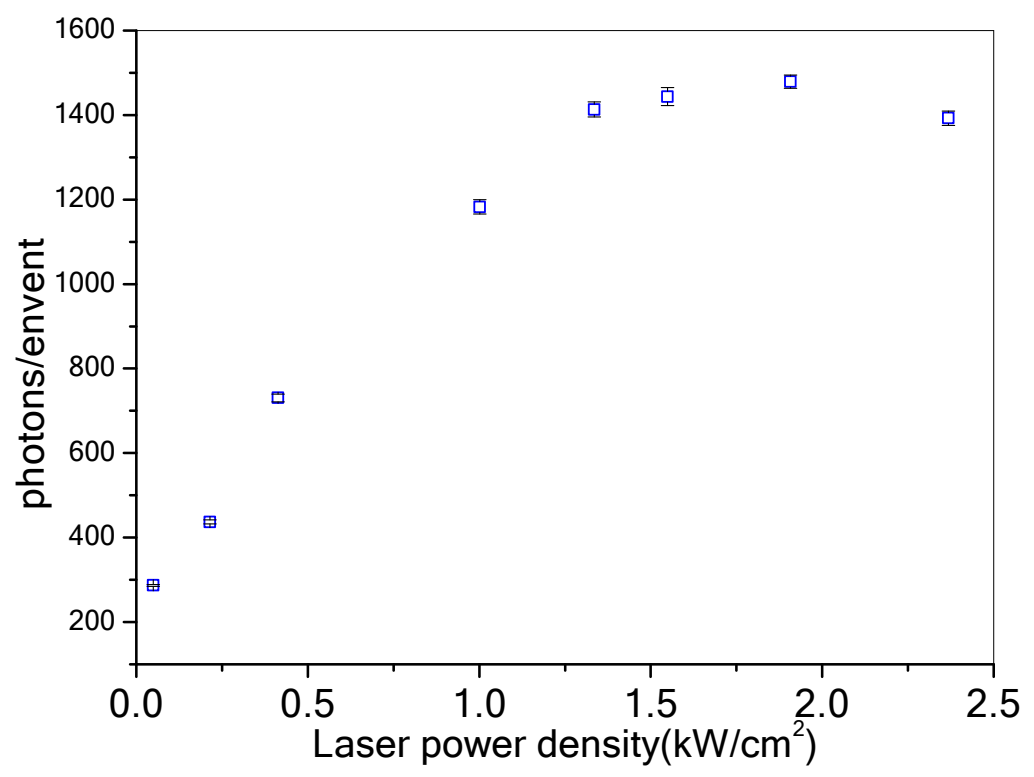

Figure S6. Excitation intensity dependency of photon number per switching event (mean \pm s.e., $\mathrm{N}=500-2000)$. The s.e. was plotted on the figure. 
(a)

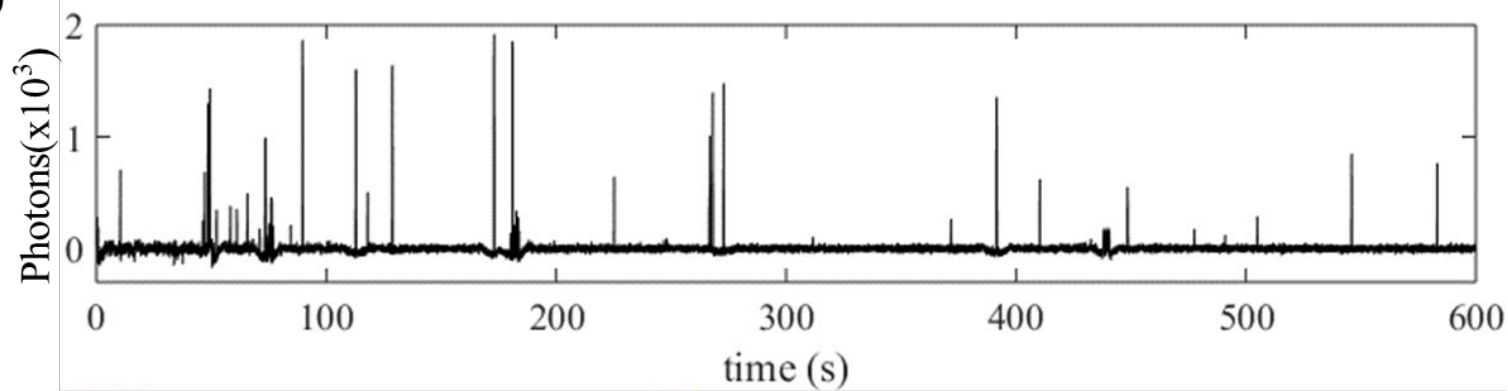

(b)
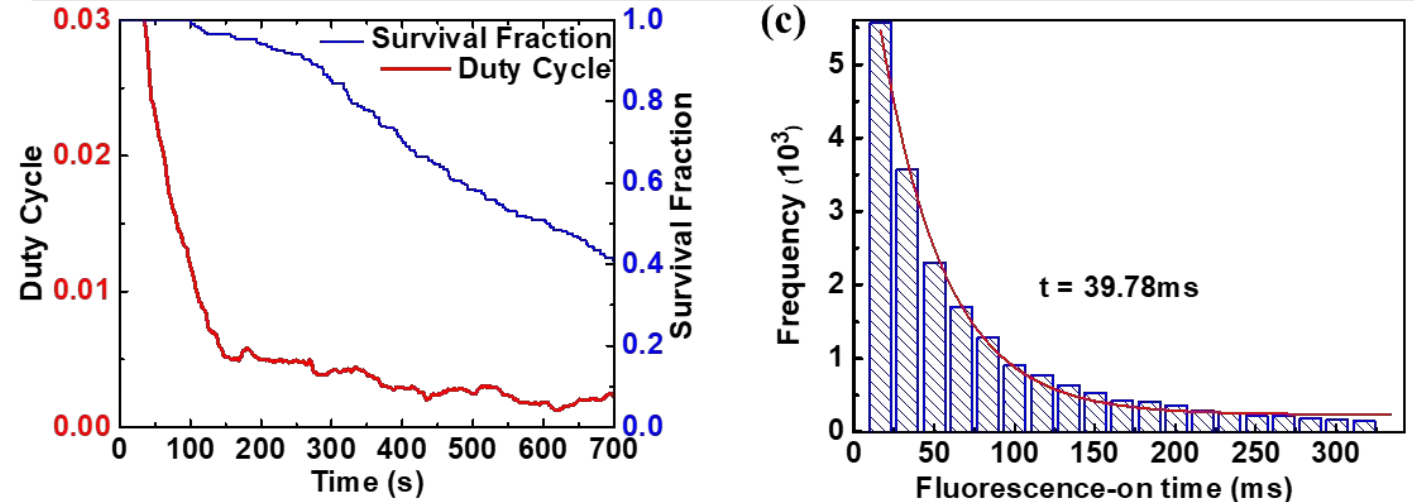

Figure S7. a) Single-molecule fluorescence time traces of Fluo-SH. b) On-off duty cycle and survival fraction plots of Fluo-SH versus time $(\mathrm{N}=500)$. c) Distribution of fluorescence-on time of Fluo-SH ( Laser power density: $1.0 \mathrm{~kW} . \mathrm{cm}^{-2}$ ).

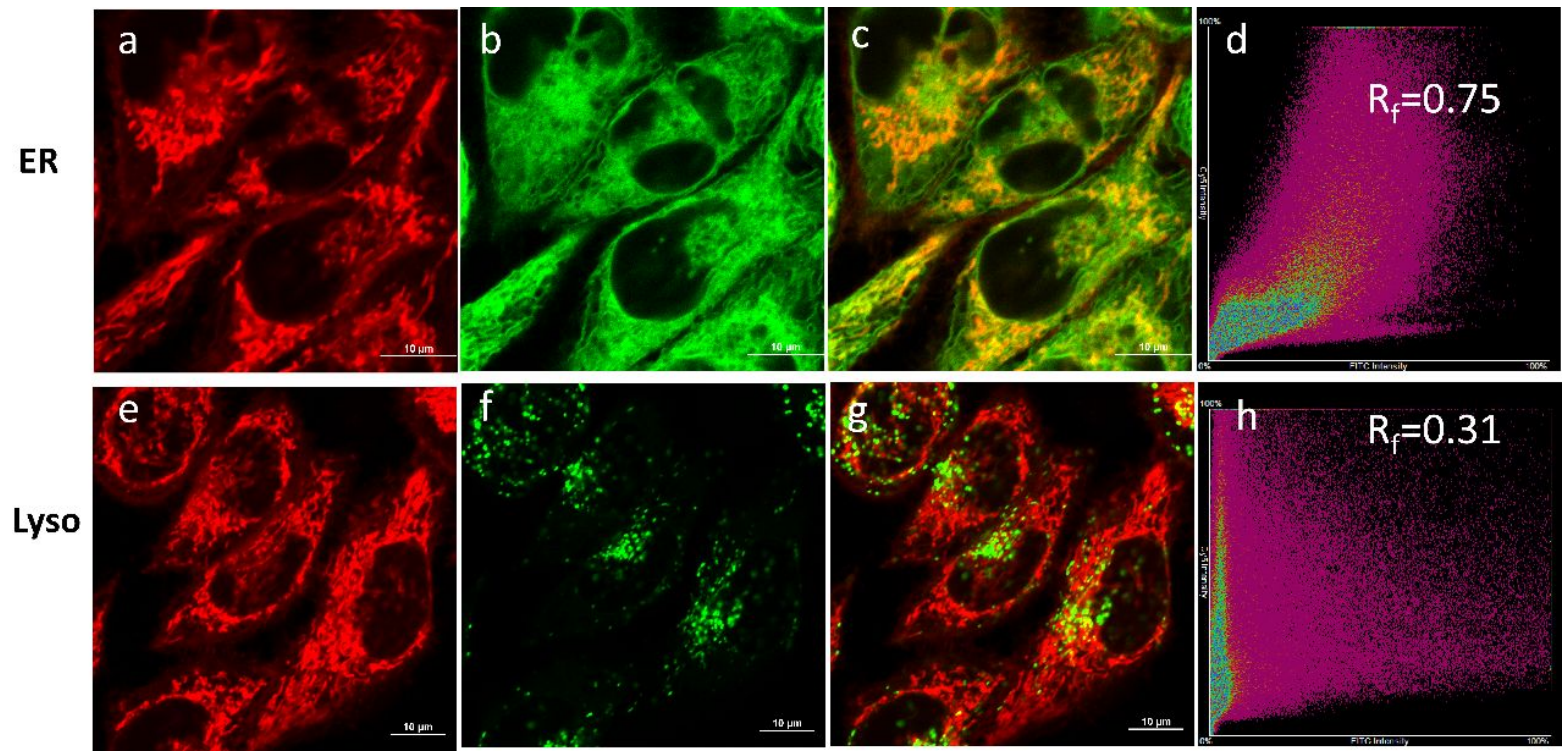

Figure S8. Fluorescence co-localization imaging of Mito-SS $(1.0 \mu \mathrm{M})$ with ER- and LysoTracker in HeLa cells, respectively. a-d) CLSM images of Hela cells stained with ER-Tracker Green $(2.0 \mu \mathrm{M})$ and Mito-SS for 30 minutes. a) Red channel. b) Green channel. c) Overlap of (a) and (b). d) Intensity correlation plot and Pearson's coefficient. e-h) CLSM images of Hela cells stained with $2 \mu \mathrm{M}$ Lyso-Tracker Green and $1 \mu \mathrm{M}$ Mito-SS for 30 minutes. e) Red channel. f) Green channel. g) Overlap of (e) and (f). h) Intensity correlation plot and Pearson's coefficient. Scale bar: $10 \mu \mathrm{m}$ 

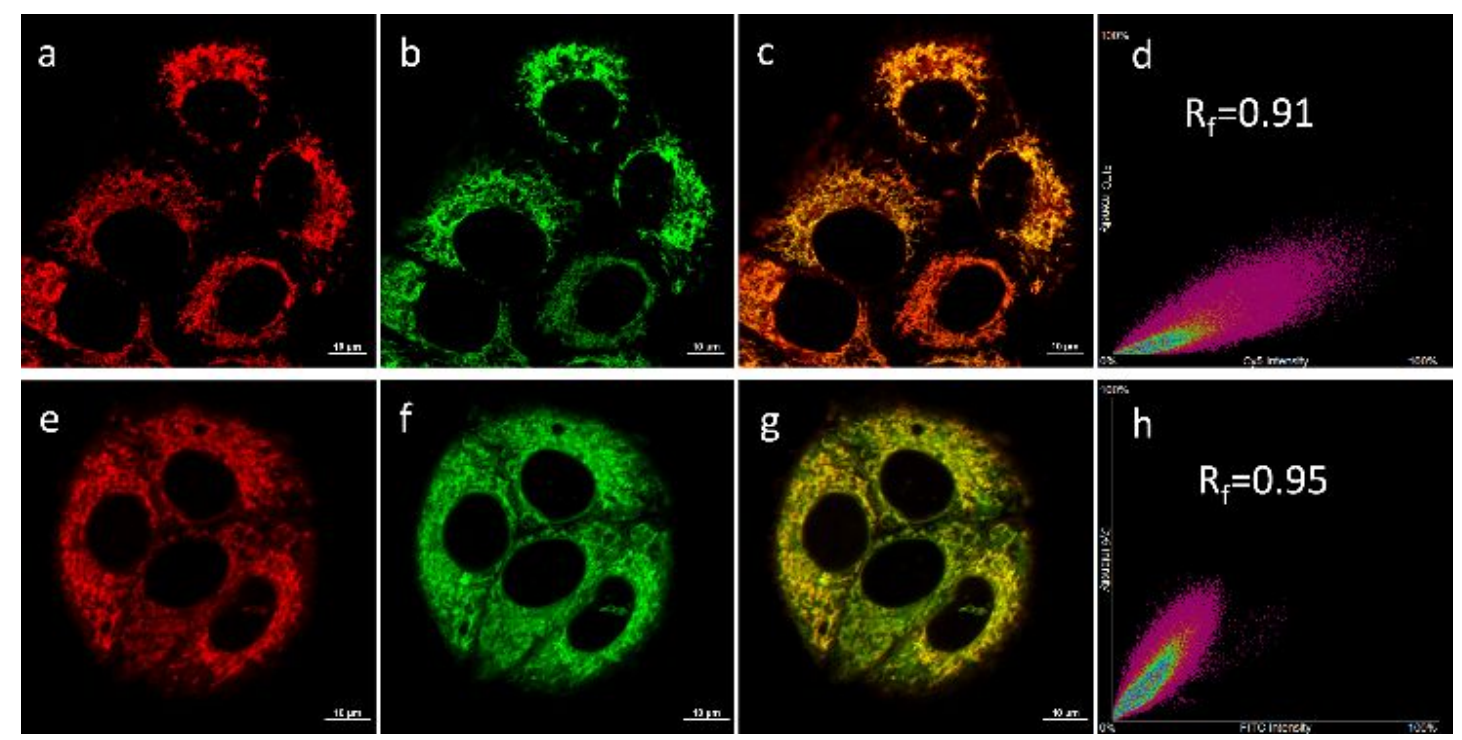

Figure S9. Fluorescence co-localization of Mito-SS and MitoTracker ${ }^{\mathrm{TM}}$ Green in HeLa cells with and without CCCP treatment. a-d) CLSM images of HeLa cells stained with MitoTracker Green ${ }^{\mathrm{TM}}(0.5 \mu \mathrm{M})$ and Mito-SS $(1.0 \mu \mathrm{M})$ for 5 minutes without CCCP. a) Red channel. b) Green channel. c) merged image of (a) and (b). d) fluorescence intensity correlation plot. e-h) CLSM images of HeLa cells stained with MitoTracker ${ }^{\mathrm{TM}}$ Green $(0.5$ $\mu \mathrm{M})$ and Mito-SS $(1.0 \mu \mathrm{M})$ for 30 minutes and treated with CCCP $(25 \mu \mathrm{M})$ for 30 minutes. e) Red channel. f) Green channel. g) Overlap of (e) and (f). h) fluorescence intensity correlation plot (scale bar $=10 \mu \mathrm{m})$.

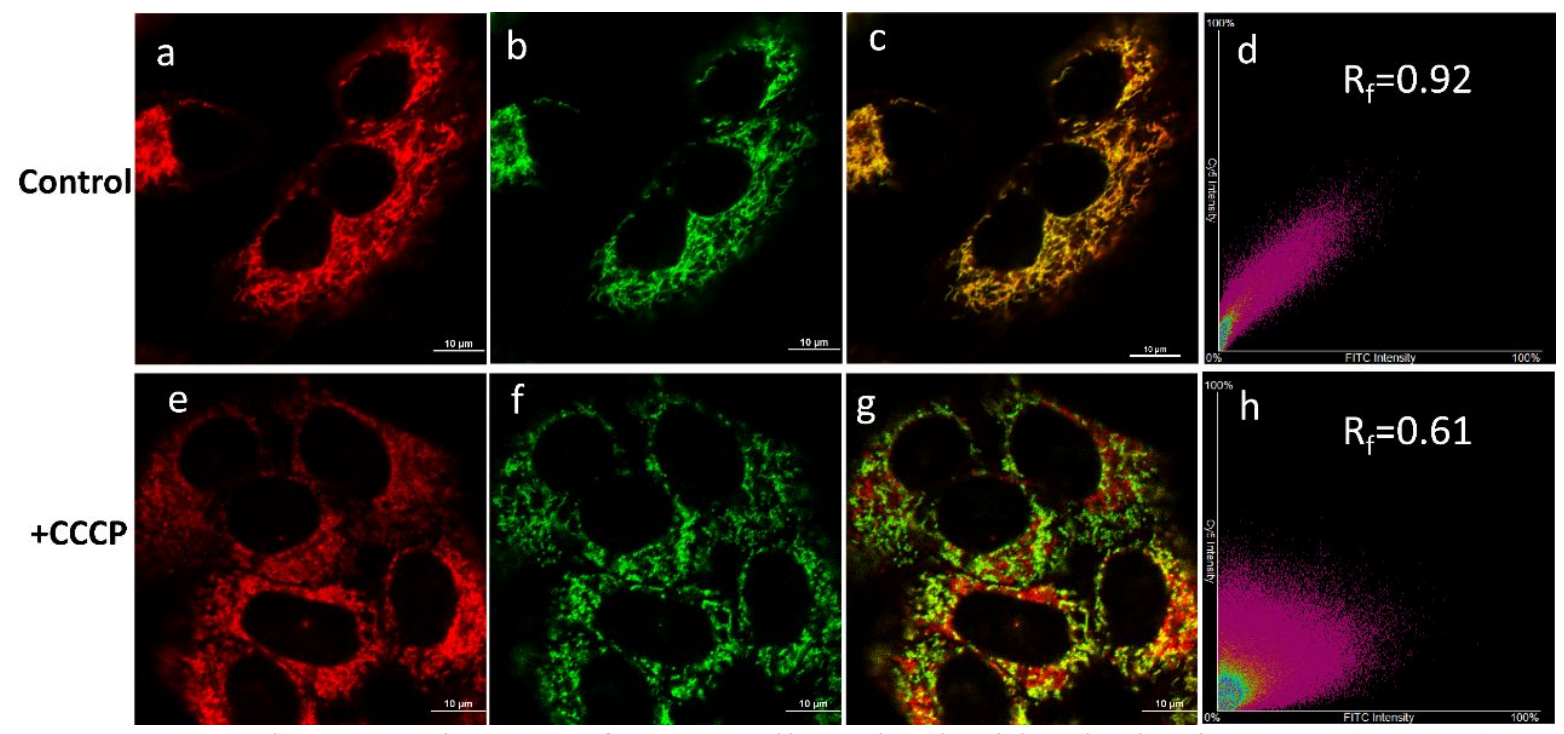

Figure S10. a-d) CLSM images of HeLa cells stained with Rhodamine $123(0.5 \mu \mathrm{M})$ and Mito-SS $(1 \mu \mathrm{M})$ for 30 minutes. a) Red channel. b) Green channel. c) Overlap of (a) and (b). d) Intensity correlation plot and Pearson's coefficient. e-h) CLSM images of Hela cells stained with $0.5 \mu \mathrm{M}$ Rhodamine 123 and $1 \mu \mathrm{M}$ Mito-SS for 30 minutes and then treated with $25 \mu \mathrm{M}$ CCCP for 30 minutes. e) Red channel. f) Green channel. g) Overlap of (e) and (f). h) Intensity correlation plot and Pearson's coefficient. Scale bar: $10 \mu \mathrm{m}$. 


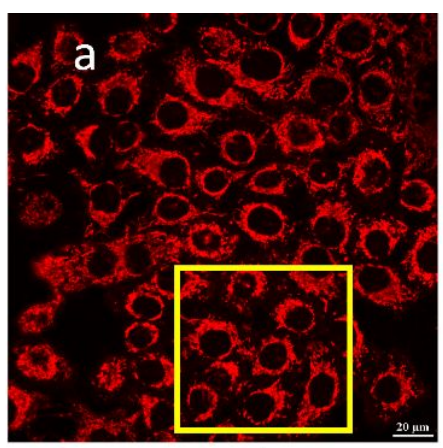

$5 \mathrm{~min}$

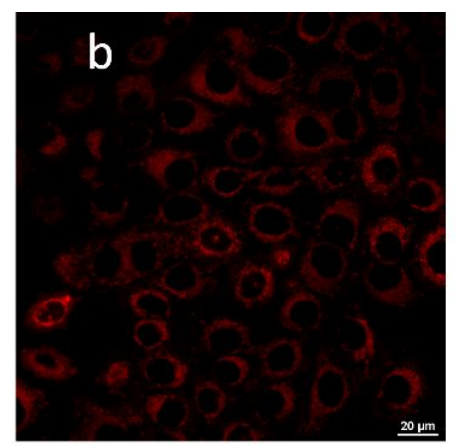

1 hour

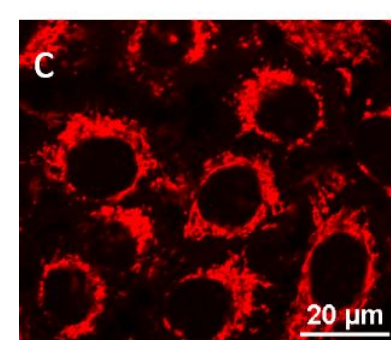

5 min

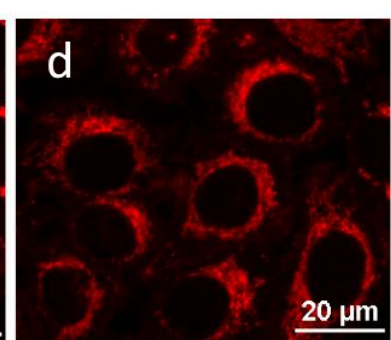

$20 \mathrm{~min}$

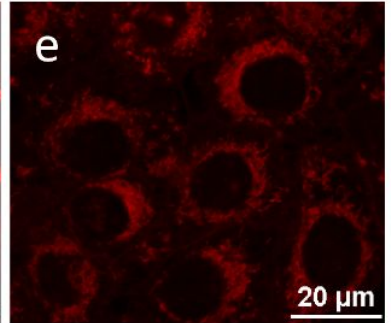

$40 \mathrm{~min}$

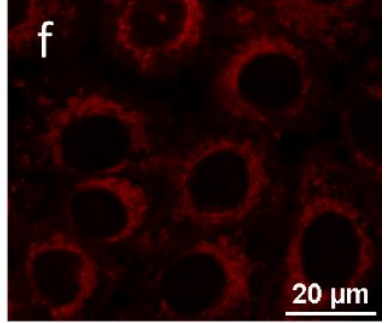

1 hour

Figure S11. CLSM images of live HeLa cells incubated with $1 \mu \mathrm{M}$ Mito-SS with different time. a, b) Full field of view of a certain area. c-f) Partial field of view noted as the yellow square in (a). Scale bar: $20 \mu \mathrm{m}$
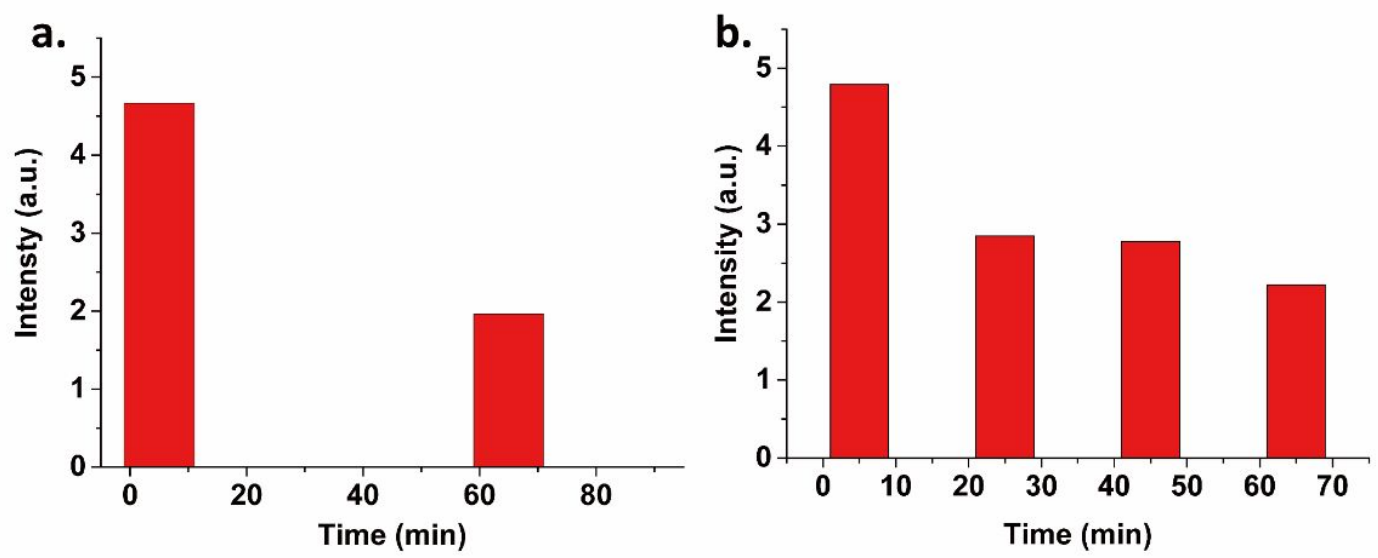

Figure S12. Quantitative comparison of fluorescent intensity in HeLa cells in the Supplementary Figure 10 calculated by image J. a) Fluorescent intensity in panels (a) and (b) of Figure S10. (b) Fluorescent intensity in panels (c-f) of Figure S10. 


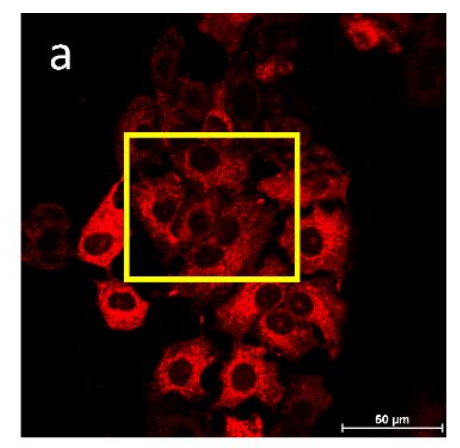

\section{$5 \mathrm{~min}$}

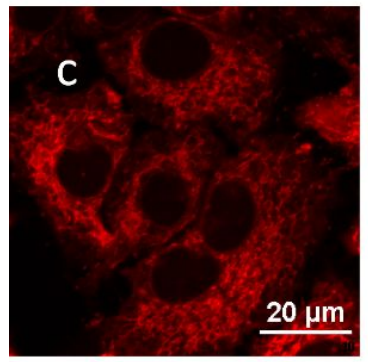

$5 \mathrm{~min}$

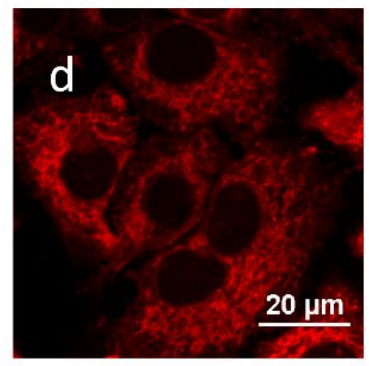

$20 \mathrm{~min}$

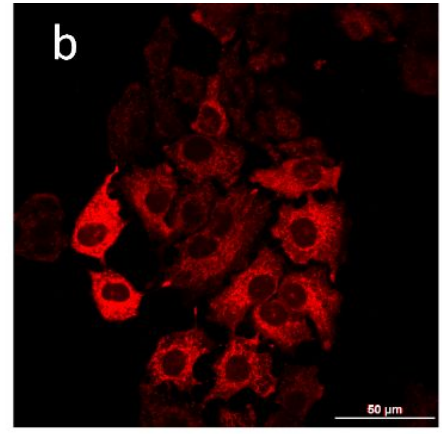

1 hour

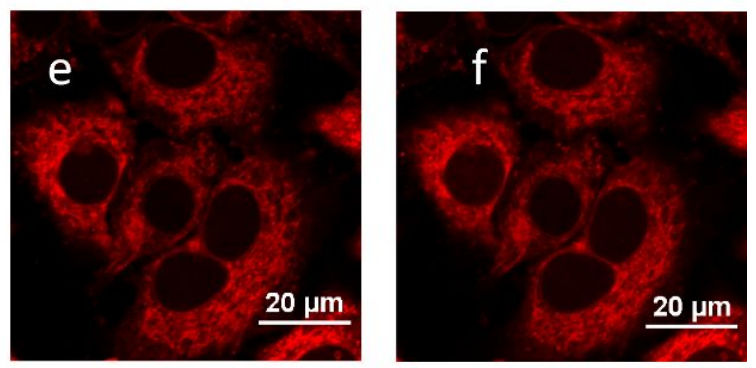

$40 \mathrm{~min}$
1 hour

Figure S13. CLSM images of live Hela cells incubated with $1 \mathrm{mM}$ NEM for 30 minutes and then incubated with $1 \mu \mathrm{M}$ Mito-SS with different time. a-b) Full field of view of a certain area (Scale bar: $50 \mu \mathrm{m}$ ). c-f): Partial field of view noted as the yellow square in (a). (Scale bar: $20 \mu \mathrm{m})$
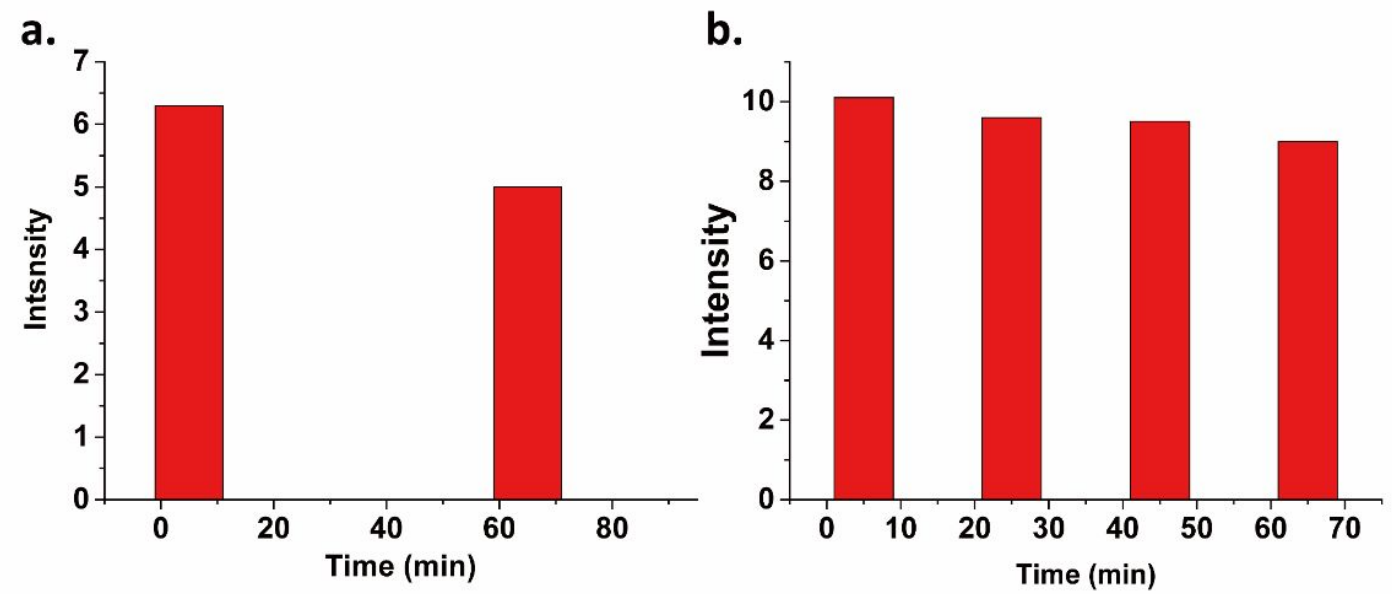

Figure S14. a) Quantitative comparison of fluorescent intensity in HeLa cells in the Supplementary Figure 12 calculated by image J. a) Fluorescent intensity in panels (a) and (b) of Figure S12. (b) fluorescent intensity in panels (c-f) of Figuer S12. 

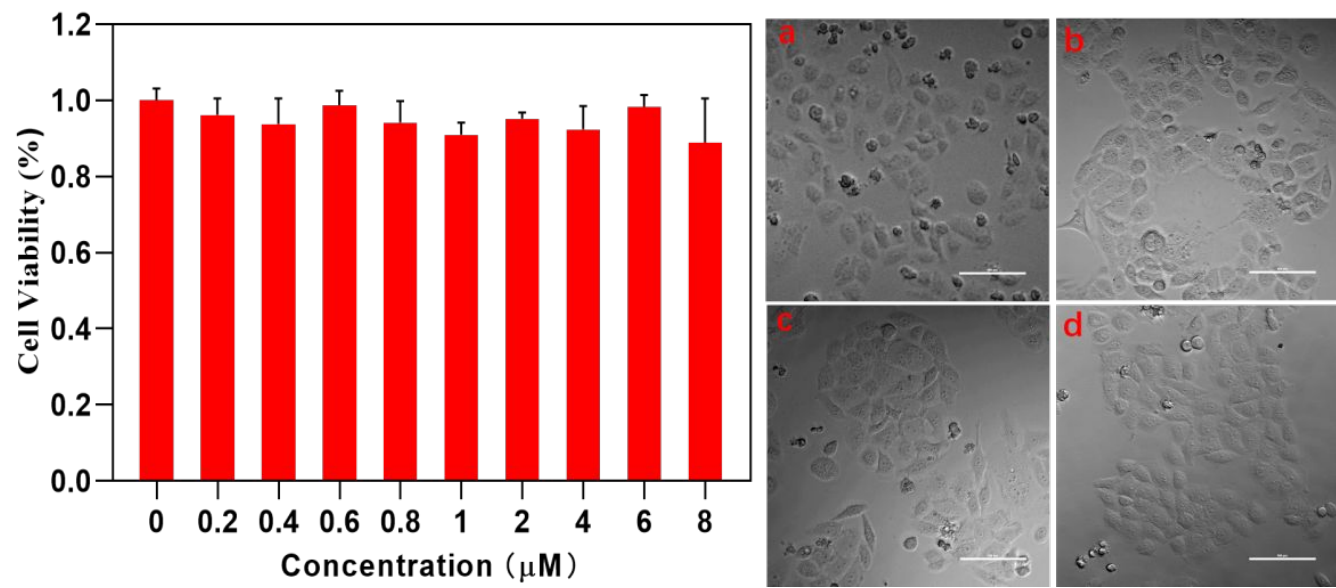

Figure S15. Cytotoxicity test of Mito-SS with CCK-8. Cells were cultured with different concentration of Mito-SS for $7 \mathrm{~h}$ and CCK- 8 was added after the first 3 hours.a: $0 \mu \mathrm{M}, \mathrm{b}: 0.2 \mu$ M, c: $1.0 \mu \mathrm{M}, \mathrm{d}: 8.0 \mu \mathrm{M}$, scale bar: $100 \mu \mathrm{m}$

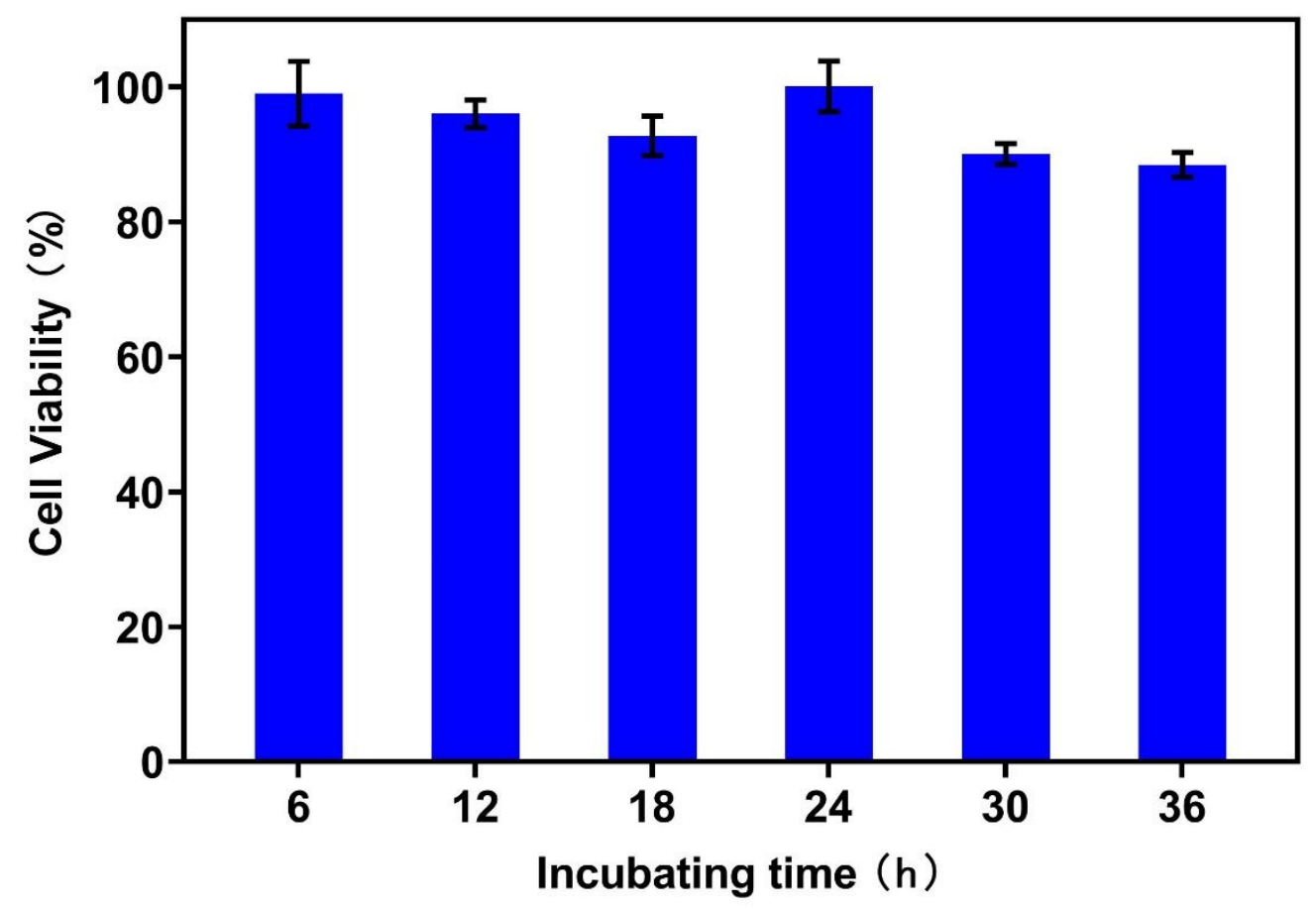

Figure S16. Cytotoxicity test of Mito-SS with CCK-8. Cells were cultured with fixed concentration of Mito-SS $(1 \mu \mathrm{M})$ for different time periods of $6,12,18,24,30$ and 36 hours 


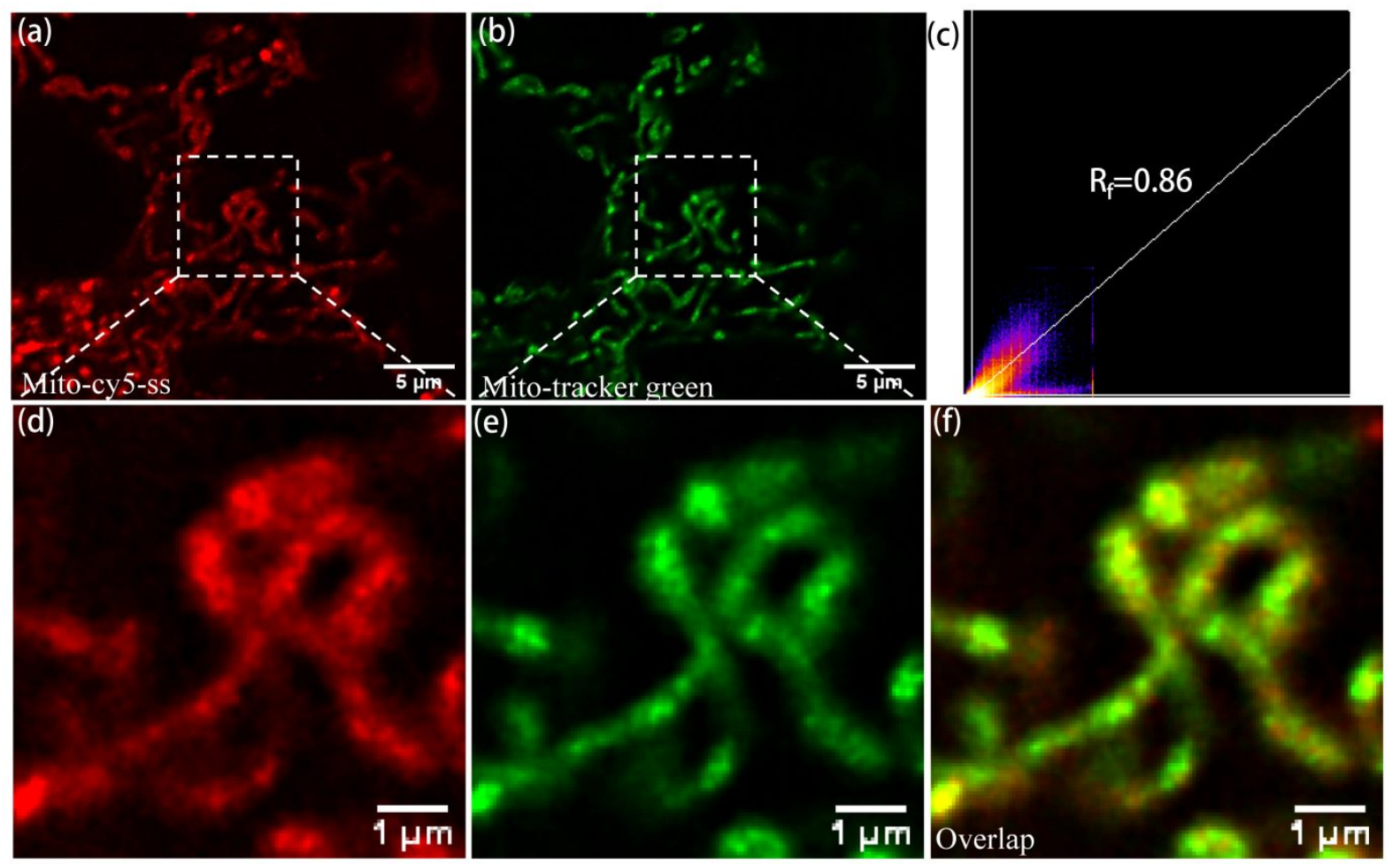

Figure S17. Colocalization Confocal imaging after deconvolution of Mito-SS and Mitotracker Green in live HeLa cells. a) Red channel (Mito-SS), scale bar: $1 \mu \mathrm{m}$. b) Green channel (Mitotracker Green), scale bar $5 \mu \mathrm{m}$. c) Intensity correlation plot and Pearson's coefficient of f. d) Mito-SS labeled ROI in a. e) Mitotracker Green labeled ROI in b. f) Overlap of $d$ and e
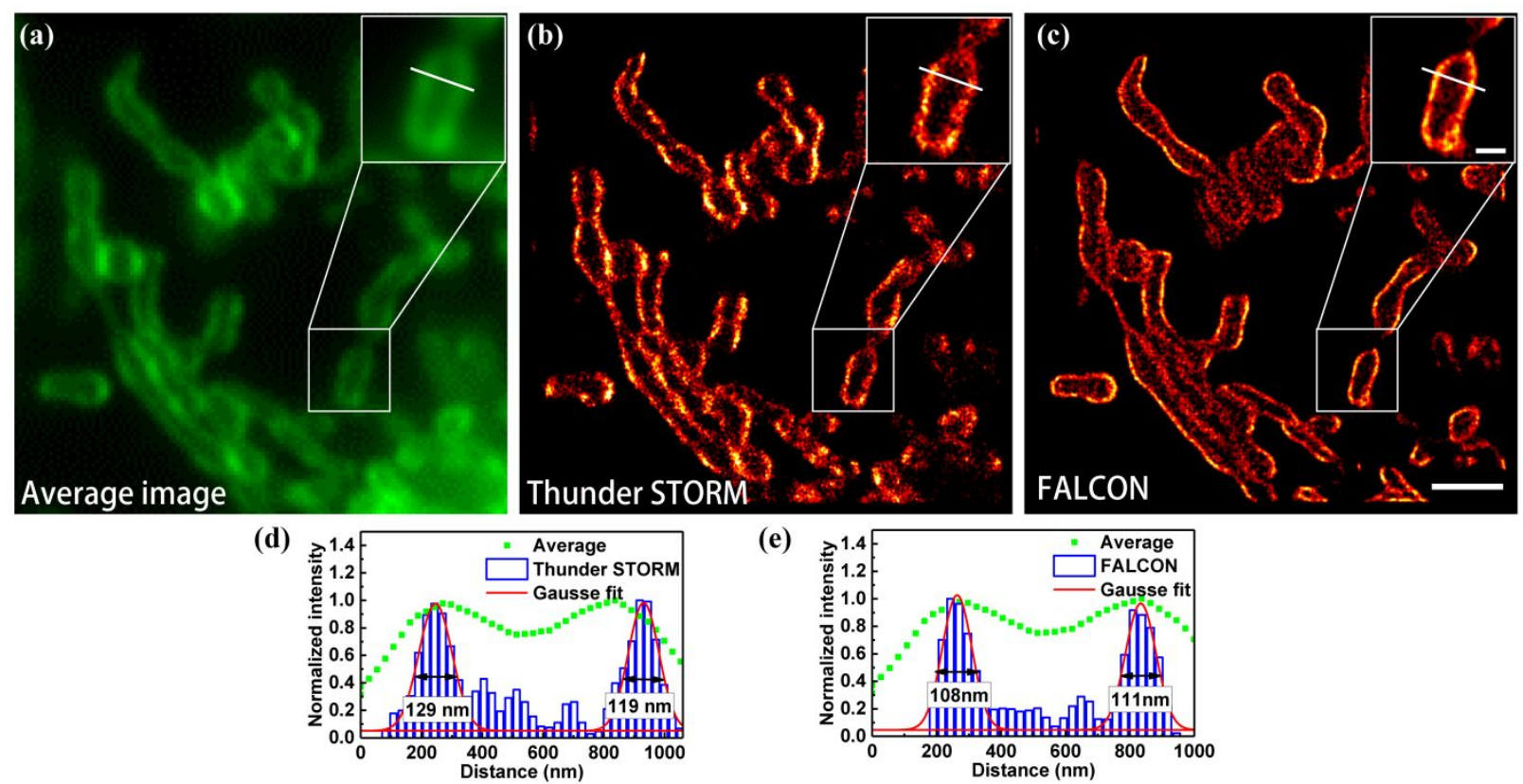

Figure S18. Wide-field and STORM imaging of live HeLa cells using Mito-SS probe. a) Average wide-filed image of mitochondria stacked with 240 frames. b) STORM image of mitochondria reconstructed with Thunder STORM(camera frequency of $60 \mathrm{~Hz}$, temporal resolution of $4 \mathrm{~s}$ ), scale bar: $2 \mu \mathrm{m}, 500 \mathrm{~nm}$. c) STORM image of mitochondria reconstructed 
with FALCON d,e) Transverse profiles of fluorescence intensity and localizations corresponding to regions marked in white bar in Panels (a), (b), (c).

\section{Experimental Section:}

Quantum yield: The quantum yield relative to Rhodamine B was calculated by $\Phi_{\text {Mito-SS }}=$ $\Phi_{\mathrm{RHB}} \cdot \mathrm{I}_{\mathrm{MIto}-\mathrm{SS}} / \mathrm{I}_{\mathrm{RHB}} \cdot \mathrm{A}_{\mathrm{RHB}} / \mathrm{A}_{\text {Mito-SS. }} \mathrm{I}_{\text {Mito-SS }}$ and $\mathrm{I}_{\mathrm{RHB}}$ refer to the integrals of the area of fluorescence spectra. $A_{\text {RHB }}$ and $A_{\text {Mito-s }}$ refer to the absorption of each dye.

Cell culture: HeLa cells were grown in Dulbecco's Modified Eagle Medium (DMEM) supplemented with $10 \%$ fetal bovine serum (FBS) and $1 \%$ penicillin and streptomycin in a $5 \% \mathrm{CO}_{2}$ incubator at $37{ }^{\circ} \mathrm{C}$. Before imaging, HeLa cells were placed on glass dishes and allowed to adhere for $48 \mathrm{~h}$.

Co-staining experiment: Mito-SS was dissolved in DMSO at a stock concentration of $1 \mathrm{mM}$. (1) In normal live cells: HeLa cells were firstly incubated with $1 \mu \mathrm{M}$ Mito-SS in PBS for 3 min, and then washed with PBS for 3 times and stained with $0.5 \mu \mathrm{M}$ Mito-Tracker Green/ 2 $\mu \mathrm{M}$ Lyso-Tracker Green/ $2 \mu \mathrm{M}$ ER-Tracker Green in DMEM containing 10\% fetal bovine serum for 5 minutes (Mito-tracker Green) or 30 minutes (Lyso- and ER-Tracker Green), and washed with PBS for 3 times. $1 \mathrm{~mL}$ DMEM containing 10\% fetal bovine serum was added to keep the cells healthy before imaging; (2) In live cells with decreased mitochondrial membrane potential (MMP): HeLa cells were firstly incubated with $1 \mu \mathrm{M}$ Mito-SS and Mitotracker Green (or Rhodamine123) for 3 minutes in PBS, washed 3 times with PBS, and $1 \mathrm{~mL}$ DMEM containing $10 \%$ fetal bovine serum was added for imaging. Then the cells were treated with $25 \mu \mathrm{M}$ carbonyl cyanide $m$-chlorophenyl hydrazone (CCCP) for 30 minutes and then used for imaging.

\section{Cytotoxicity assay.}

Cytotoxicity assays of the Mito-SS were performed on HeLa cells and cell viability was determined using Cell Counting Kit-8 (CCK-8) assay. Initially, HeLa cells were seeded in a 96-well plate to control the cell density of 10000 cells per well and incubated in a humidified incubator for adherence.

(1) After $24 \mathrm{~h}$ of culturing, the medium in each well was replaced by $100 \mu \mathrm{L}$ of fresh medium (RPMI-1640) containing different concentrations of the probe (Mito-SS, 1-8 $\mu \mathrm{M}$ ). After incubating for 3 hours, the detecting ragent (CCK-8 diluted by RPMI-1640 medium (10\%) ) was added to the corresponding wells and continued to incubate for another 4 hours,

(2) After $24 \mathrm{~h}$ of culturing, the medium in each well was replaced by $100 \mu \mathrm{L}$ of fresh medium (RPMI-1640) containing $1 \mu \mathrm{M}$ of the probe Mito-SS. The solution was filtrated by $0.22 \mu \mathrm{m}$ sterile filter. The volume fraction of DMSO was below $0.2 \%$. After incubating 6, 12, 18, 24, 30, 36h, respectively, CCK-8 reagent, diluted by RPMI-1640 medium (10\%) was added to the corresponding wells after the removal of culture media and incubated for 3 hours,

Following above steps, the absorbance was measured at $450 \mathrm{~nm}$ on a plate reader (RT-6100, Rayto Life and Analytical Sciences Co., Ltd, Shenzhen, China). Each trial was performed with six parallel wells. Cell viability rate was determined as VR $=\left(A_{s}-A_{b}\right) /\left(A_{c}-A_{b}\right) \times 100 \%$, 
where As is the absorbance of the experimental group, Ac is the absorbance of the control group (no probe Mito-SS), and Ab is the absorbance of the blank group (no cells).

Super resolution microscopy setup: Super-resolution microscopy imaging was performed on an inverted optical microscope (Nikon Ti2-A). A 656-nm solid-state laser beam (460 mW; CNI Laser China) was used for activation of the red dyes. The power of laser irradiance was controlled by a neutral density filter kit (Optical Densities from 0.1 to 4.0, THORLABS). The fluorescent signal was collected by an oil-immersion objective (PlanApo $\lambda, 100 \mathrm{x}$, NA 1.45, Nikon), pass through a custom filter set (LED-DA/FI/TR/Cy5-4X4M-B-000; Semrock), separated with a long pass filter (BLP01-488R-25; Semrock) and focused onto an EMCCD camera (iXon Ultra 897; Andor). An open source package written in python was used for the acquisition of STORM raw data (http://zhuang.harvard.edu/). Typically, the images were taken at 60 frames per second for $256 \times 256$ pixels $(\sim 160 \mathrm{~nm}$ per pixel) and 120 frames per second for ROI of $128 \times 128$ pixels under wide-field illumination.

To stabilize the microscope focus during data acquisition, a $785 \mathrm{~nm}$ solid-state laser beam was used as referencet light ${ }^{[3]}$. The laser was coupled into the optical path through the dichroic mirror. When the angle is greater than or equal to the total internal reflection angle, the total internal reflection of the reference light occurs at the interface between the cover glass and the biological sample. The reflected red excitation laser from the glass-water interface was directed onto a quadrant photodiode (PDQ80A, THORLABS)by a reflective prism at the back port of the microscope. The quadrant photodiode read the position of the reflected laser, which was sensitive to the distance between the coverglass surface and the objective. This information was then fed back to a z-positioning piezo stage (P-725.2CD, PI) by software to correct for the z-drift in the microscope focus. This "focus lock" system was capable of maintaining the focus position within $10 \mathrm{~nm}$ for the duration of STORM data acquisition.

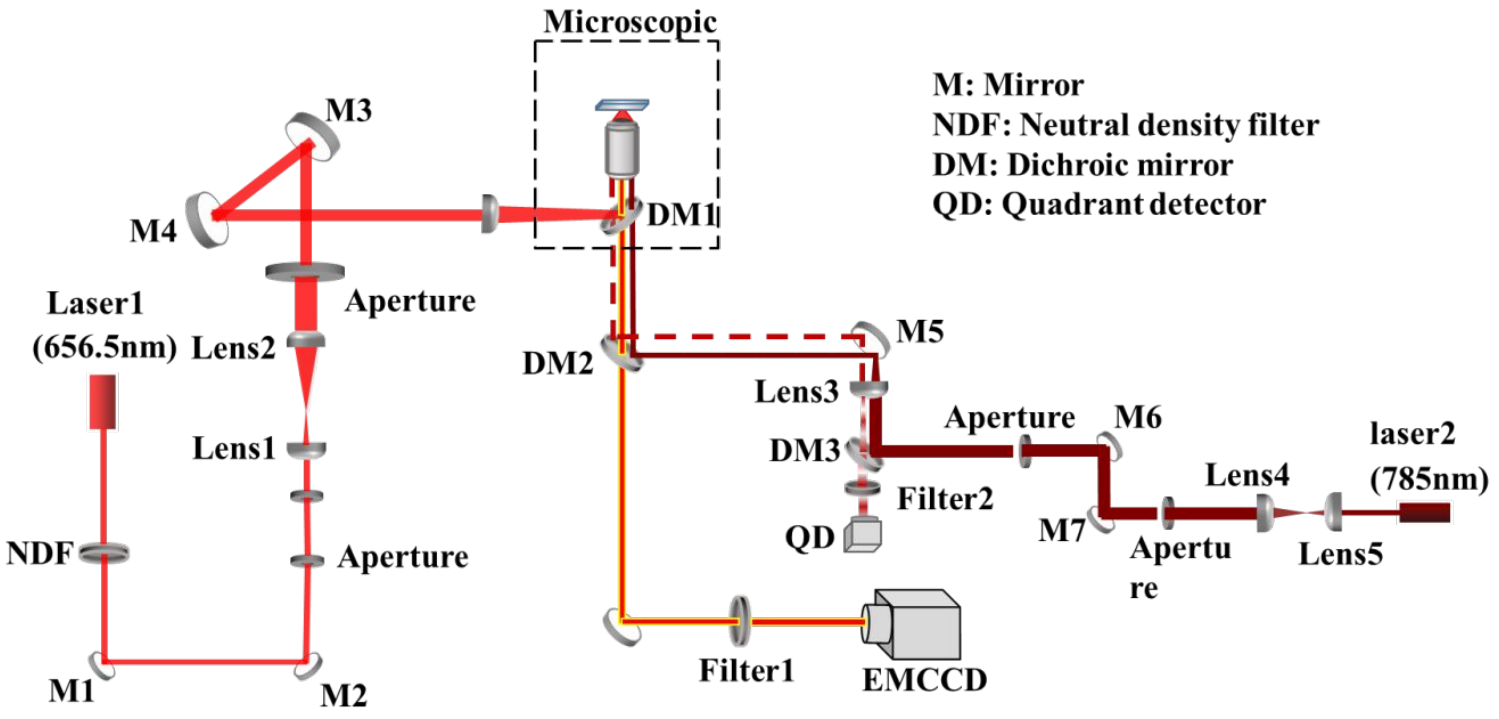

Figure S19. Schematic of the home-built STORM imaging system

STORM imaging experiment: Mito-SS was dissolved in DMSO at a stock concentration of $1 \mathrm{mM}$. HeLa cells were firstly incubated with $1 \mu \mathrm{M}$ Mito-SS in PBS for 3 minutes, washed 
with PBS for 3 times, and then incubated in $1 \mathrm{~mL}$ DMEM containing $10 \%$ fetal bovine serum for 1 hour in room temperature before imaging.

SLM was carried out using inverted microscope (Nikon Ti2-A) with $\times 100$, NA 1.45 oil objective lens and an electron-multiplying charge-coupled device (EMCCD) camera (iXon Ultra 897; Andor). Fluorophores were excited with a $656 \mathrm{~nm}$ laser and images were recorded at 8 or $16 \mathrm{~ms} /$ frame. Super-resolution images were constructed using FALCON algorithm. ${ }^{[4]}$

\section{Data analysis:}

Single-molecule fluorescence blinking behavior: Fluo-SH were adsorbed on the surface of coverslip. 50000 frames were recorded at a frame rate of $15 \mathrm{~ms} /$ frame. Data included duty cycle, surival fraction and fluorescence-on time were analyzed according to reported method ${ }^{3}$. Single-molecule fluorescence time traces were calculated for each molecule by analyzing the total integrated signal in a $5 \times 5$-pixel $(156 \mathrm{~nm}$ per pixel) region centered on the molecule during each frame of the movie. 50-120 molecules were analyzed for each condition using MATLAB (Math Works). The number of photons was calculated as the total intensity count minus the background intensity count, which was converted to photon number using the calibrated parameter for electron multiplication and analog-to-digital conversion gain settings used during acquisition. Fluorescence switching events were identified within the time traces by identifying signal changes with a magnitude that is greater than 5-10 times the s.d. of the background fluctuations of the fluorescence time trace.

The on-off duty cycle, DC, of the dyes was calculated within a sliding window of $100 \mathrm{~s}$ as

$$
D C=\left\langle\frac{\sum_{i} \tau_{o n, i}}{100 s}\right\rangle
$$

where $\tau_{\mathrm{on}, \mathrm{i}}$ denotes the on-time of the $\mathrm{i}^{\text {th }}$ switching event for a given molecule within the time window, and the brackets indicate averaging over all molecules not yet photobleached. The equilibrium duty cycle reported was the average of the duty cycle value between 400-600 s. Photobleached molecules were not included in the duty cycle calculation for times past photobleaching. Survival fraction is the fraction of dyes not yet photobleached, for the first $700 \mathrm{~s}$ of illumination although the total movie was $1000 \mathrm{~s}$ long. Therefore, only molecules that photobleached within the first $700 \mathrm{~s}$ need to be identified. Fluorescence-on time was calculated as the time when the fluorescence signal of Fluo-SH is above a threshold of 4 times the s.d. of the fluctuations of detected background signal. Then the fluorescence-on time was hist. And the lifetime $\tau$ is the time value of exponential fit decaying to $1 / \mathrm{e}$.

Super-resolution imaging: All data were analyzed using fast localization algorithm based on a continuous-space formulation (FALCON) as previously described. ${ }^{[4]}$ Single molecules were identified and segmented in the raw images and then fitted using the FALCON algorithm. The optimal parameters for FALCON were set empirically through a comprehensive trial and error process, such that spurious detections are minimized. All reconstructed movies were made, with each frame being a single STORM image acquired over 2-4 seconds (240 frames of raw data) at EMCCD frequency of $60-120 \mathrm{~Hz}$, and with slideshow of 20 frames. The respective time resolutions were already added in the supporting information page 2-3. The FWHM values of the intensity line profiles were obtained by fitting them to a Gaussian 
distribution. We reconstructed all STORM data on an Intel i5 - 2.85 GHz CPU, and a NVidia GeForce Gtx 1060 GPU with 6 GB of video memory.

And the raw data of figure S16b was analyed using the Image $\mathrm{J}$ plugin thunderSTORM ${ }^{[5]}$ with input parameters adjusted to the imaging setup used. Briefly, images were wavelet filtered, thresholded using the local maximum approach and fitted with sub-pixel accuracy by Maximum likelihood estimation with multi-emitter fitting as implemented in thunderSTORM.

\section{Width distribution of mitochondrial tubules:}

According to video S5, STORM images revealed thin, extended tubular intermediates connecting neighboring mitochondria prior to fission, or formed by mitochondira individually. The width of tubule was computed by fitting line profiles across individual tubule with a Gaussian function using Origin. And 31 samples were analyzed to get a histagram.

\section{Synthetic Procedures:}
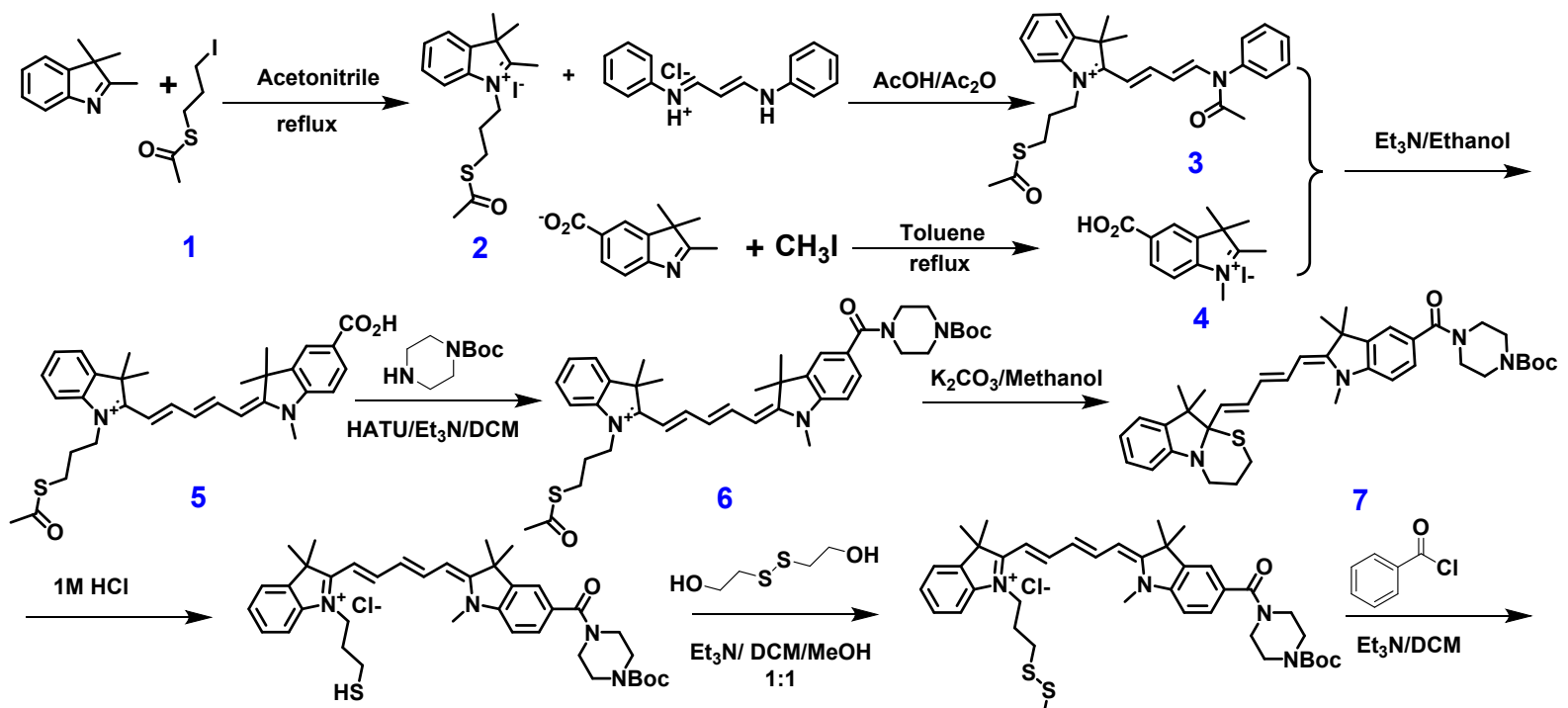

Fluo-SH

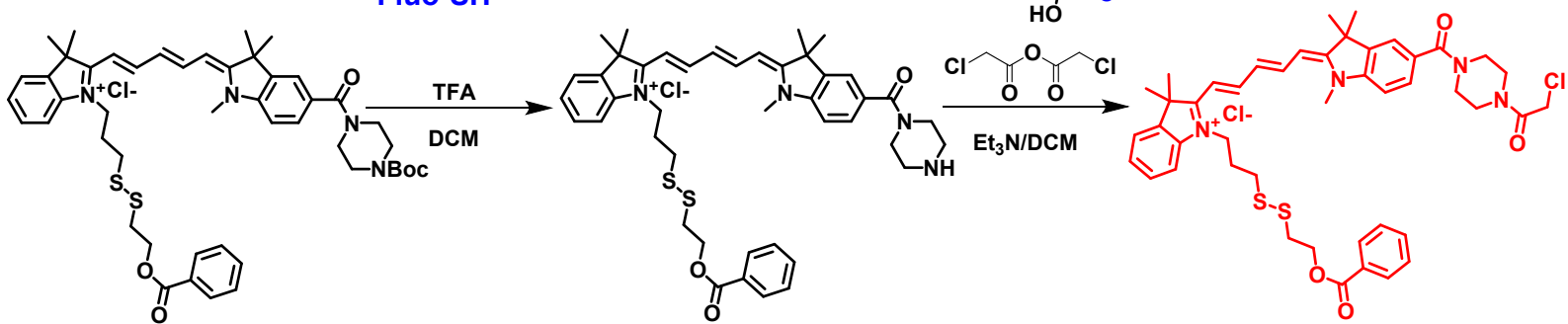

9

10

Mito-SS

Scheme S1 Synthetic route of Mito-SS and reference compounds

Compound 1 was synthesized according to Ref. 4 from the starting material 1-Bromo-3chloropropane. ${ }^{[6]}$

Compound 4 was synthesized according to Ref. 5 and 6 from the starting material 4Hydrazinobenzoic acid. ${ }^{77,8]}$

\section{Compound 2}


Compound 1 (3.66 g, $15 \mathrm{mmol}$ ) and 2, 3, 3-trimethyl-3H-indole (2.38 g, $15 \mathrm{mmol})$ were dissolved in acetonitrile $(30 \mathrm{ml})$ and refluxed overnight. After cooling to room temperature, most solvent was evaporated and $30 \mathrm{ml}$ ether was added to generate sticky purple oil. The fluid was carefully poured and the sticky oil was dissolved with minimum amount of DCM. $30 \mathrm{ml}$ ether was added to generate purple oil again, and the fluid was carefully poured. The oil ( $2.4 \mathrm{~g}$, yield: $40 \%$ ) was thoroughly dried with rotary evaporator and directly used in the next step.

\section{Compound 3}

Compound 2 (1.2 g, $3 \mathrm{mmol})$ and malonaldehyde dianilide hydrochloride $(0.78 \mathrm{~g}, 3 \mathrm{mmol})$ were dissolved with a mixture of acetic acid and acetic anhydride $(1: 1,15 \mathrm{~mL})$ and heated to reflux for 1 hour and cooled to room temperature. Most solvent was evaporated and $30 \mathrm{ml}$ ether was added. The solid residue was collected and purified through column chromatography. The dark yellow solid was directly used in the next step ( $0.86 \mathrm{~g}$, yield: $50 \%)$.

\section{Compound 5}

Compound 3 (0.574 g, $1 \mathrm{mmol})$ and compound 4 (0.345 g, $1 \mathrm{mmol})$ were dissolved in ethanol $(10 \mathrm{~mL}), \mathrm{Et}_{3} \mathrm{~N}(1 \mathrm{~mL})$ was added and the whole was refluxed for 2 hours until one of the starting materials were completely consumed monitored through TLC. The solvents were evaporated and the solid residue was purified column chromatography using DCM/MeOH as eluent to get the dark blue solid $(0.4 \mathrm{~g}$, yield $60 \%)$.

${ }^{1} \mathrm{H}$ NMR (400 MHz, DMSO) $\delta 12.88(\mathrm{~s}, 1 \mathrm{H}), 8.38(\mathrm{~m}, J=20.6,13.0 \mathrm{~Hz}, 2 \mathrm{H}), 8.11(\mathrm{~d}, J=1.4$ $\mathrm{Hz}, 1 \mathrm{H}), 7.96(\mathrm{dd}, J=8.4,1.5 \mathrm{~Hz}, 1 \mathrm{H}), 7.67(\mathrm{~d}, J=7.3 \mathrm{~Hz}, 1 \mathrm{H}), 7.43(\mathrm{~m}, J=18.4,8.1 \mathrm{~Hz}$, $3 \mathrm{H}), 7.29(\mathrm{dd}, J=11.2,4.1 \mathrm{~Hz}, 1 \mathrm{H}), 6.60(\mathrm{t}, J=12.4 \mathrm{~Hz}, 1 \mathrm{H}), 6.47(\mathrm{~d}, J=14.0 \mathrm{~Hz}, 1 \mathrm{H}), 6.23$ $(\mathrm{d}, J=13.5 \mathrm{~Hz}, 1 \mathrm{H}), 4.24(\mathrm{t}, J=6.6 \mathrm{~Hz}, 2 \mathrm{H}), 3.56(\mathrm{~s}, 3 \mathrm{H}), 3.00-2.89(\mathrm{~m}, 2 \mathrm{H}), 2.31(\mathrm{~s}, 3 \mathrm{H})$, $1.93(\mathrm{dd}, J=13.9,6.7 \mathrm{~Hz}, 2 \mathrm{H}), 1.69(\mathrm{~d}, J=3.8 \mathrm{~Hz}, 12 \mathrm{H})$.

${ }^{13} \mathrm{C}$ NMR (75 MHz, DMSO) $\delta 195.61,175.16,172.69,167.50,155.97,154.07,147.14$, $142.20,142.01,141.28,130.95,129.00,126.70,126.56,126.51,126.00,123.74,123.09$, $112.12,110.61,105.35,103.65,49.98,48.60,43.39,31.50,31.08,28.05,27.53,27.33,26.04$, 23.27 .

Chemical formula: $\mathrm{C}_{32} \mathrm{H}_{37} \mathrm{~N}_{2} \mathrm{O}_{3}$ S. ESI-MS (positive) m/z: calculated for $[\mathrm{M}]^{+}$529.25, found 529.0 .

\section{Compound 6}

Compound 5 (0.32g, $0.5 \mathrm{mmol}), 1$-boc-piperazine $(0.18 \mathrm{~g}, 1 \mathrm{mmol})$ and $\mathrm{Et}_{3} \mathrm{~N}(0.14 \mathrm{ml}, 1$ mmol) was dissolved in DCM $(20 \mathrm{ml})$, HATU $(0.38 \mathrm{~g}, 1 \mathrm{mmol})$ was added to the solution. The whole was stirred at room temperature for 3 hours and then washed with $0.1 \mathrm{M} \mathrm{HCl}$ solution and brine. The organic phase was separated and dried. After removing the solvent, the solid residue was purified through column to get blue solid $(0.33 \mathrm{~g}$, yield: $80 \%)$ ${ }^{1} \mathrm{H}$ NMR (400 MHz, $\left.\mathrm{CDCl}_{3}\right) \delta 7.96(\mathrm{dd}, \mathrm{J}=13.3,3.3 \mathrm{~Hz}, 2 \mathrm{H}), 7.48-7.36(\mathrm{~m}, 4 \mathrm{H}), 7.28(\mathrm{~d}, \mathrm{~J}$ $=2.7 \mathrm{~Hz}, 1 \mathrm{H}), 7.18(\mathrm{~d}, \mathrm{~J}=8.1 \mathrm{~Hz}, 1 \mathrm{H}), 7.12(\mathrm{~d}, \mathrm{~J}=8.7 \mathrm{~Hz}, 1 \mathrm{H}), 6.68(\mathrm{~s}, 1 \mathrm{H}), 6.27(\mathrm{~d}, \mathrm{~J}=$ $13.7 \mathrm{~Hz}, 1 \mathrm{H}), 6.13$ (d, J = 13.4 Hz, 1H), $4.12(\mathrm{dd}, \mathrm{J}=9.8,4.9 \mathrm{~Hz}, 2 \mathrm{H}), 3.58(\mathrm{~s}, 7 \mathrm{H}), 3.48$ (s, 4H), 2.99 (t, J = 7.1 Hz, 2H), 2.35 (s, 3H), $1.71(\mathrm{~d}, \mathrm{~J}=9.3 \mathrm{~Hz}, 12 \mathrm{H}), 1.47$ (s, 9H). 
${ }^{13} \mathrm{C} \mathrm{NMR}\left(75 \mathrm{MHz}, \mathrm{CDCl}_{3}\right) \delta 195.57,195.55,174.37,172.69,169.99,154.58,154.54,153.20$, $144.31,141.64,141.45,141.17,131.38,128.82,128.23,126.75,125.90,122.45,121.71$, $110.92,109.91,104.57,103.59,80.42,49.84,48.97,43.22,31.36,30.70,28.36,27.88,27.76$, 25.98 .

Chemical formula: $\mathrm{C}_{41} \mathrm{H}_{53} \mathrm{~N}_{4} \mathrm{O}_{4} \mathrm{~S}$. ESI-MS (positive) m/z: calculated for $[\mathrm{M}]^{+}$697.38, found 697.0.

\section{Fluo-SH}

Compound $6(0.1 \mathrm{~g}, 0.12 \mathrm{mmol})$ was dissolved in methanol $5 \mathrm{ml}, \mathrm{K}_{2} \mathrm{CO}_{3}(60 \mathrm{mg}, 0.4 \mathrm{mmol})$ was added and the whole was stirred at room temperature for $30 \mathrm{~min}$. The reaction was monitored by HPLC-MS. After the starting material was completely consumed, the reaction was diluted with $20 \mathrm{ml} \mathrm{DCM}$ and washed with $1 \mathrm{M} \mathrm{HCl}$ aqueous solution. The whole was shaken vigorously until the organic phase was completely blue. The organic phase was dried and the organic solvent was evaporated to get blue solid directly used as Fluo-SH $(80 \mathrm{mg}$, yield: 99\%). To get Compound 7, the organic solution was washed with saturated $\mathrm{NaHCO}_{3}$ solution. The organic phase was separated and dried with anhydrous sodium sulfate. After filtration, DCM was evaporated and yellow to green solid was obtained (quantity). The HNMR of ring-closed form of Fluo-SH (7) was shown in supplementary figure 5. Chemical formula for Fluo-SH: $\mathrm{C}_{39} \mathrm{H}_{51} \mathrm{~N}_{4} \mathrm{O}_{3} \mathrm{~S}$. ESI-MS (positive) $\mathrm{m} / \mathrm{z}$ : calculated for $[\mathrm{M}]^{+}$655.37, found 655 .

\section{Compound 8:}

Fluo-SH $(0.327 \mathrm{~g}, 0.5 \mathrm{mmol})$ was dissolved in a mixture of DCM and methanol (10 $\mathrm{ml}, 1: 1)$, Bis(2-hydroxyethyl) Disulfide $(1.54 \mathrm{~g}, 10 \mathrm{mmol})$ and $\mathrm{Et}_{3} \mathrm{~N}(0.14 \mathrm{ml}, 1 \mathrm{mmol})$ was added. The solution was stirred at room temperature for 24 hours and washed with water, extracted with DCM and the organic phase was dried and concentrated. The residue was dissolved with $1 \mathrm{ml}$ DCM, $0.1 \mathrm{ml} \mathrm{Et}_{3} \mathrm{~N}$ and $1 \mathrm{ml} \mathrm{EtOAc}$ was added. Excess ether was added to participate the disulfide compound and remove the ring-closed starting material. The process was carried out twice and the solid was purified through flash column chromatography with $\mathrm{DCM} / \mathrm{MeOH}$ (20:1) as eluent to get get pure compound 8. A little hexane was added to get blue solid. (0.11 g, yield: 29\%)

${ }^{1} \mathrm{H}$ NMR (400 MHz, $\left.\mathrm{CDCl}_{3}\right) \delta 8.03-7.82(\mathrm{~m}, 2 \mathrm{H}), 7.47-7.35(\mathrm{~m}, 4 \mathrm{H}), 7.28-7.21(\mathrm{~m}, 2 \mathrm{H})$, $7.10(\mathrm{~d}, J=8.6 \mathrm{~Hz}, 1 \mathrm{H}), 6.73(\mathrm{~s}, 1 \mathrm{H}), 6.39(\mathrm{~d}, J=13.7 \mathrm{~Hz}, 1 \mathrm{H}), 6.14(\mathrm{~d}, J=13.4 \mathrm{~Hz}, 1 \mathrm{H})$, $4.22(\mathrm{t}, J=7.3 \mathrm{~Hz}, 2 \mathrm{H}), 3.89(\mathrm{t}, J=5.9 \mathrm{~Hz}, 2 \mathrm{H}), 3.57(\mathrm{~s}, 7 \mathrm{H}), 3.48(\mathrm{~s}, 4 \mathrm{H}), 2.87(\mathrm{dt}, J=13.4$, $6.3 \mathrm{~Hz}, 4 \mathrm{H}), 2.33-2.18(\mathrm{~m}, 2 \mathrm{H}), 1.73(\mathrm{t}, J=10.4 \mathrm{~Hz}, 12 \mathrm{H}), 1.48(\mathrm{~s}, 9 \mathrm{H})$.

${ }^{13} \mathrm{C} \mathrm{NMR}\left(75 \mathrm{MHz}, \mathrm{CDCl}_{3}\right) \delta 174.45,172.33,170.03,154.59,152.88,144.36,141.64,141.44$, $141.11,131.23,128.92,128.22,126.94,125.97,122.37,121.72,111.18,109.79,104.97$, $103.56,80.45,60.31,49.81,48.86,42.87,40.96,34.50,31.27,29.69,28.36,27.94,27.82$, 26.22 .

Chemical formula: $\mathrm{C}_{41} \mathrm{H}_{55} \mathrm{~N}_{4} \mathrm{O}_{4} \mathrm{~S}_{2}$. ESI-MS (positive) $\mathrm{m} / \mathrm{z}$ : calculated for $[\mathrm{M}]^{+} 731.37$, found 731.

\section{Mito-SS}


Compound 8 (0.23 g, $0.3 \mathrm{mmol})$ was dissolved in DCM and benzoyl chloride (70 mg,0.5 mmol) was added to the solution and stirred at room temperature for 20 minutes. After washing with water, the organic phase was dried and evaporated. The residue was dissolved with $1 \mathrm{~mL}$ DCM and excess ether was added to generate pure compound 9 (0.2 g, $78 \%)$ which was directly subjected to the next step.

Compound 9 (0.17 g, $0.2 \mathrm{mmol})$ was dissolved in a mixture of DCM and TFA (10 ml, 3:1) and stirred at room temperature for 1 hour. The volatile was evaporated and residue was diluted with DCM and washed with water, saturated $\mathrm{NaHCO}_{3}$ aqueous solution and the organic phase was dried and concentrated to get blue solid 10 (quantitative) which was directly used in the next step. The blue solid was dissolved in DCM and chloroacetic anhydride ( $86 \mathrm{mg}, 0.5 \mathrm{mmol}$ ) was added followed by addition of $\mathrm{Et}_{3} \mathrm{~N}(0.07 \mathrm{~mL}, 0.5 \mathrm{mmol})$. The solution was stirred for 1 hour at room temperature and washed with water. The organic solution was dried and the volatile was evaporated. The residue was purified through column chromatograph to get pure Mito-SS (0.136 g, yield 80\%, three steps yield 53\%).

${ }^{1} \mathrm{H}$ NMR $\left(300 \mathrm{MHz}, \mathrm{CDCl}_{3}\right) \delta 8.31-8.07(\mathrm{~m}, 2 \mathrm{H}), 8.03(\mathrm{~d}, J=7.2 \mathrm{~Hz}, 2 \mathrm{H}), 7.56(\mathrm{t}, J=7.4$ $\mathrm{Hz}, 1 \mathrm{H}), 7.50-7.33(\mathrm{~m}, 6 \mathrm{H}), 7.23(\mathrm{t}, J=7.8 \mathrm{~Hz}, 2 \mathrm{H}), 7.12(\mathrm{~d}, J=8.0 \mathrm{~Hz}, 1 \mathrm{H}), 6.83(\mathrm{t}, J=$ $11.9 \mathrm{~Hz}, 1 \mathrm{H}), 6.66(\mathrm{~d}, J=13.5 \mathrm{~Hz}, 1 \mathrm{H}), 6.21(\mathrm{~d}, J=13.2 \mathrm{~Hz}, 1 \mathrm{H}), 4.58(\mathrm{t}, J=6.4 \mathrm{~Hz}, 2 \mathrm{H})$, $4.32(\mathrm{~s}, 2 \mathrm{H}), 4.16(\mathrm{~s}, 2 \mathrm{H}), 3.67(\mathrm{~d}, J=36.4 \mathrm{~Hz}, 11 \mathrm{H}), 3.07(\mathrm{t}, J=6.4 \mathrm{~Hz}, 2 \mathrm{H}), 2.94(\mathrm{~s}, 2 \mathrm{H})$, $2.26(\mathrm{~s}, 2 \mathrm{H}), 1.73(\mathrm{~d}, J=8.4 \mathrm{~Hz}, 12 \mathrm{H})$.

${ }^{13} \mathrm{C}$ NMR $\left(75 \mathrm{MHz}, \mathrm{CDCl}_{3}\right) \delta 174.49,172.12,170.04,166.29,165.51,155.17,153.34,144.56$, $141.61,141.42,141.05,133.15,130.48,129.71,129.57,128.75,128.38,128.31,127.23$, $125.78,122.33,121.84,110.98,109.71,105.39,103.62,62.71,49.70,48.74,46.17,42.84$, 42.10, 40.88, 36.84, 34.89, 31.62, 26.14.

Chemical formula: $\mathrm{C}_{45} \mathrm{H}_{52} \mathrm{ClN}_{4} \mathrm{O}_{4} \mathrm{~S}_{2}$. HRMS (positive) $\mathrm{m} / \mathrm{z}$ : calculated for $[\mathrm{M}]^{+} 811.3119$, found 811.3104 . 
Structural identification of target compounds:

Compound $5{ }^{1} \mathrm{H}-\mathrm{NMR}$ ( $400 \mathrm{MHz}$, DMSO- $d^{6}$ )

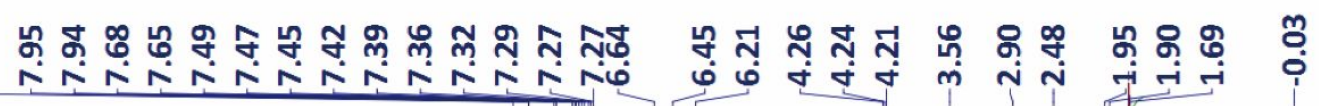
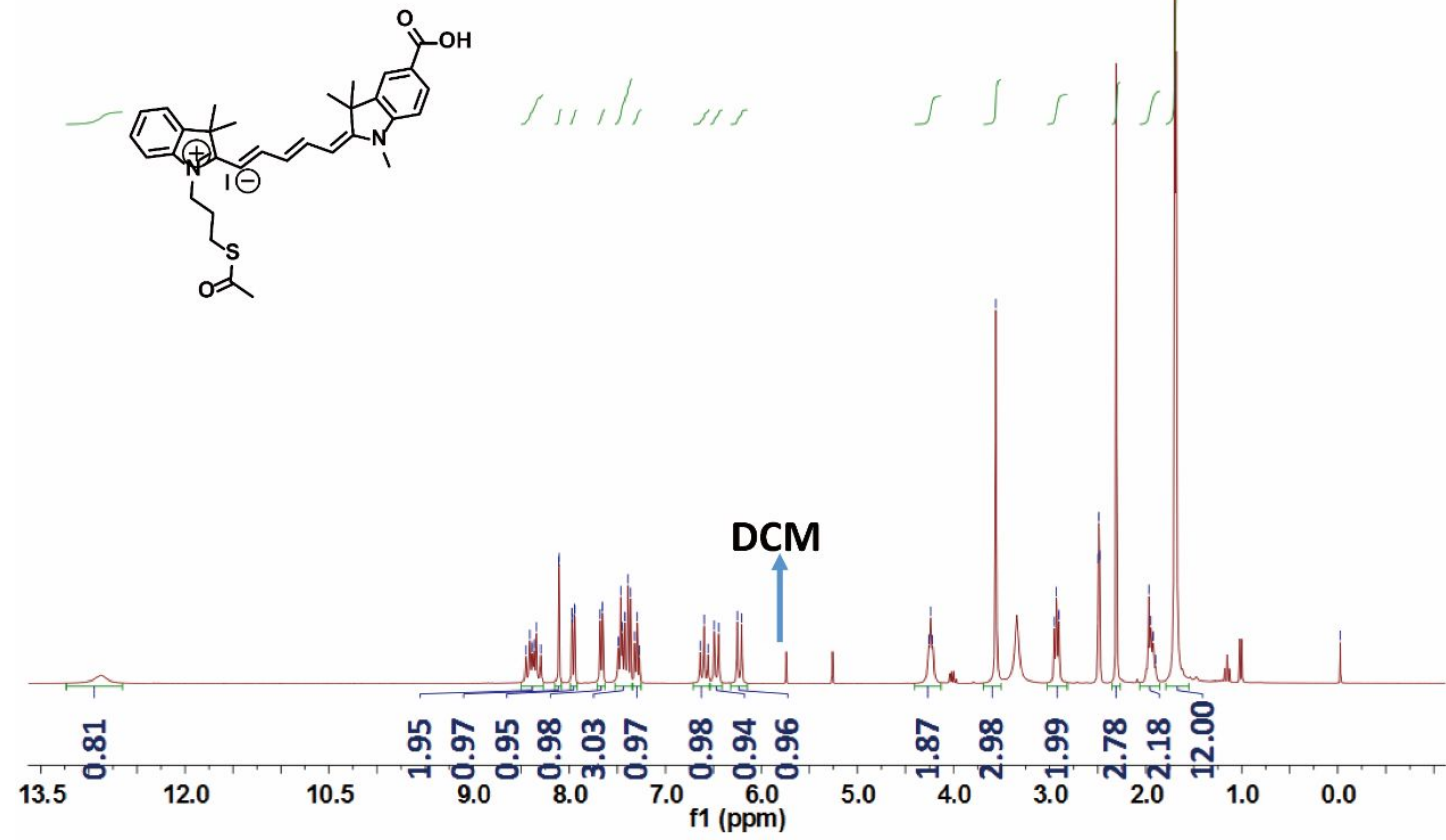

Compound $5{ }^{13} \mathrm{C}-\mathrm{NMR}\left(100 \mathrm{MHz}\right.$, DMSO- $\left.d^{6}\right)$

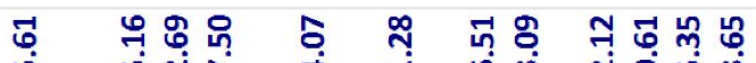

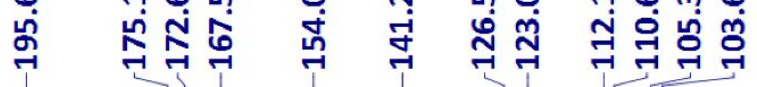

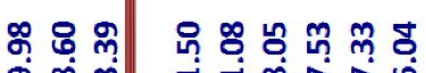

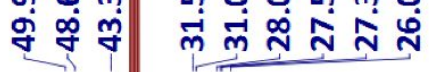

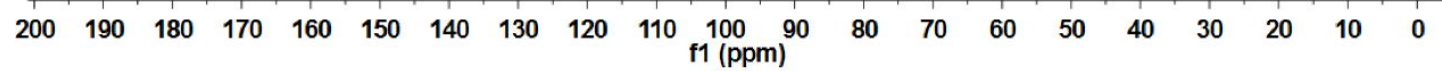


Compound $6{ }^{1} \mathrm{H}-\mathrm{NMR}\left(400 \mathrm{MHz}, \mathrm{CDCl}_{3}\right)$

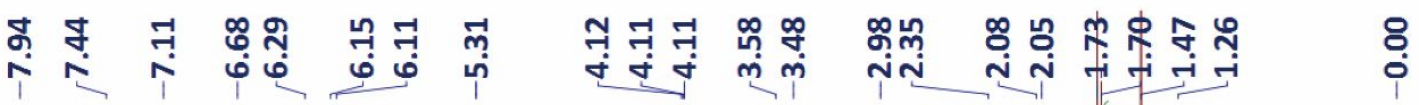

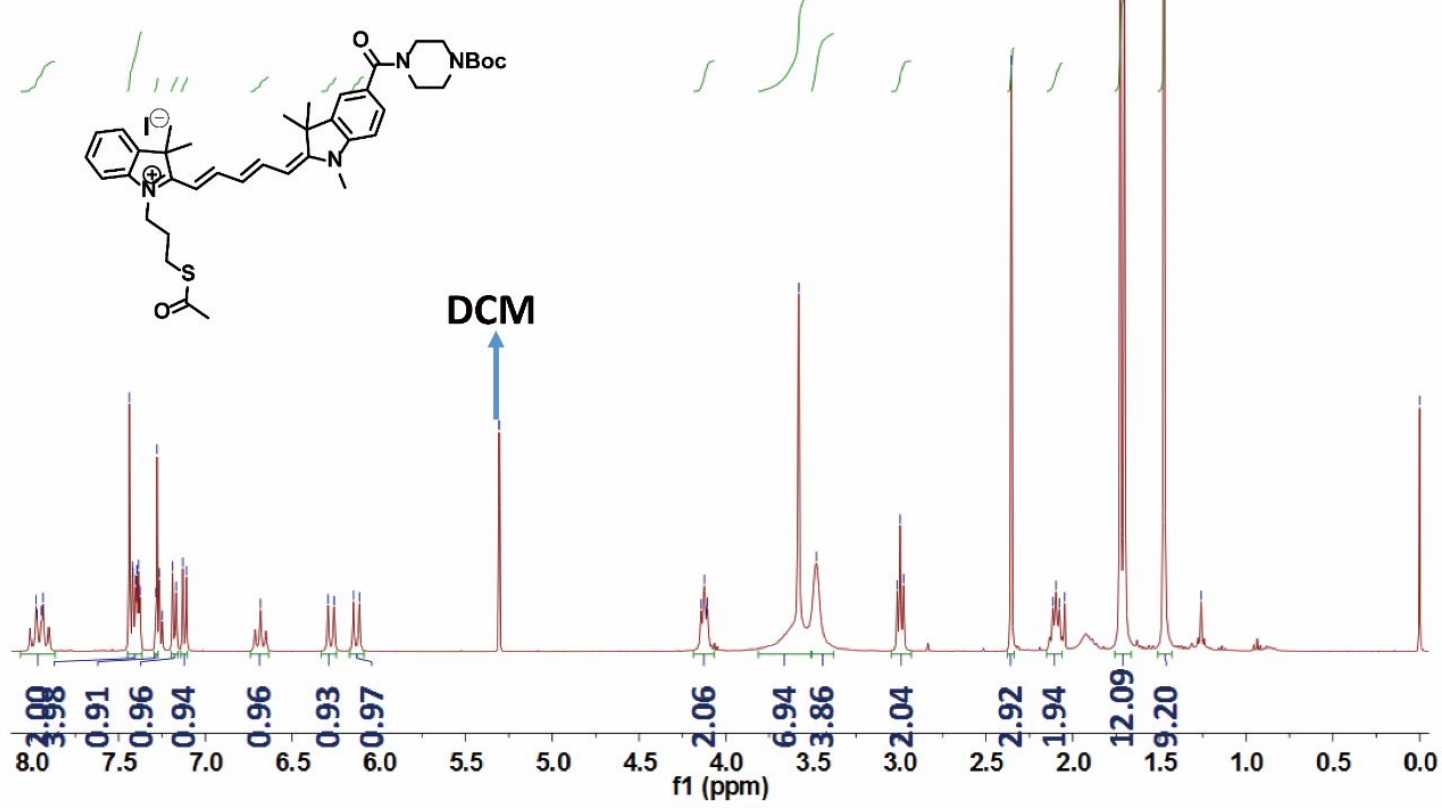

Compound $6{ }^{13} \mathrm{C}-\mathrm{NMR}\left(100 \mathrm{MHz}, \mathrm{CDCl}_{3}\right)$

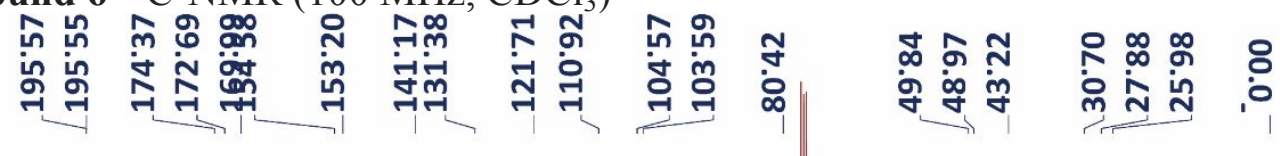

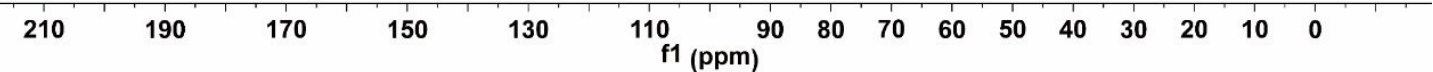


Compound $8{ }^{1} \mathrm{H}-\mathrm{NMR}\left(400 \mathrm{MHz}, \mathrm{CDCl}_{3}\right.$ )

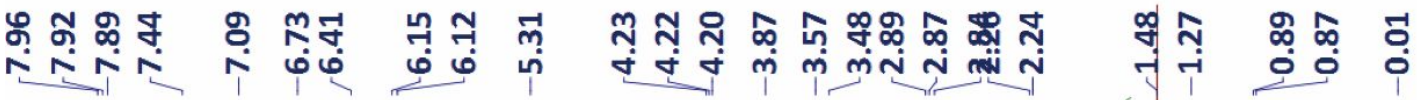
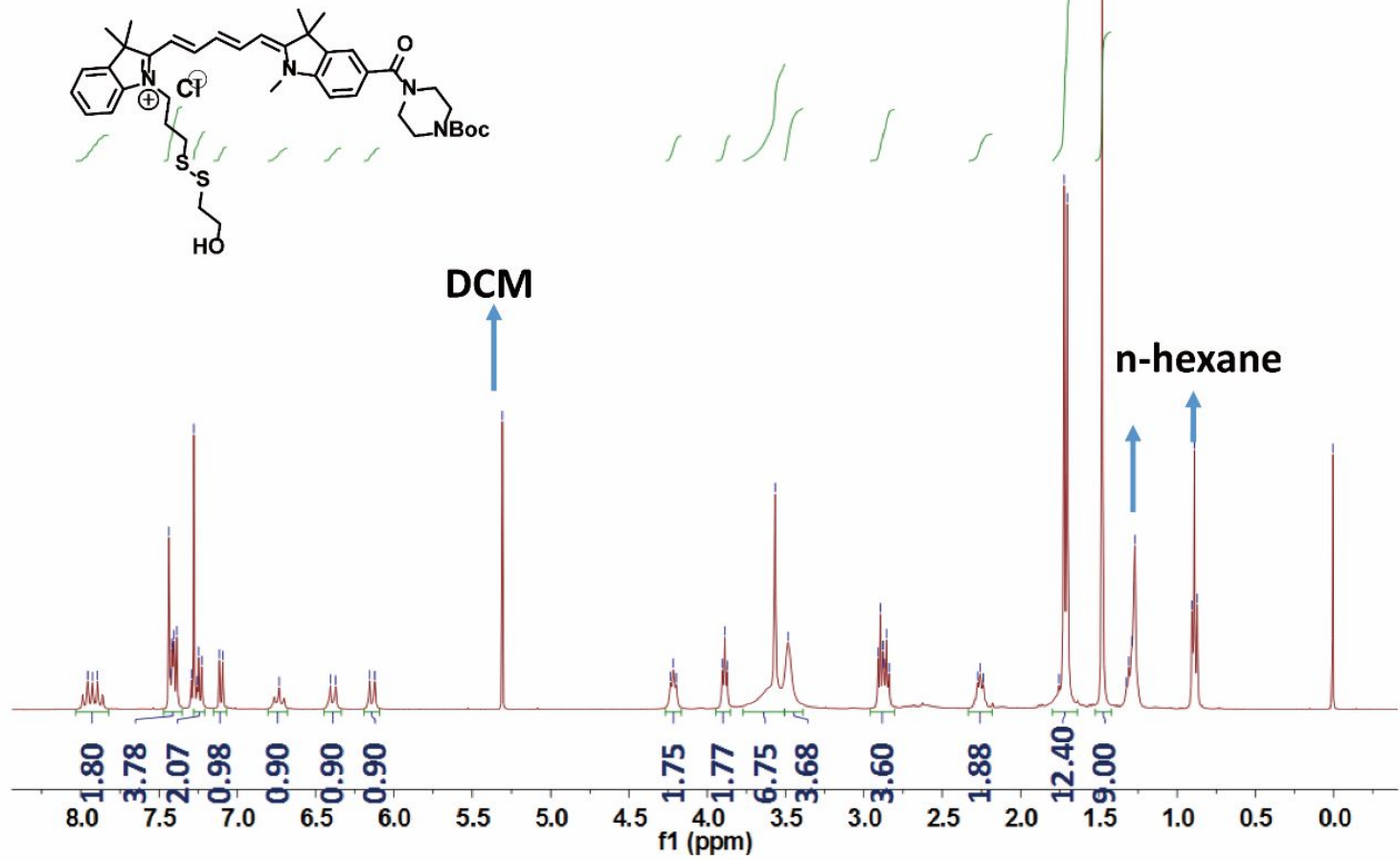

Compound $8{ }^{13} \mathrm{C}-\mathrm{NMR}\left(100 \mathrm{MHz}, \mathrm{CDCl}_{3}\right)$

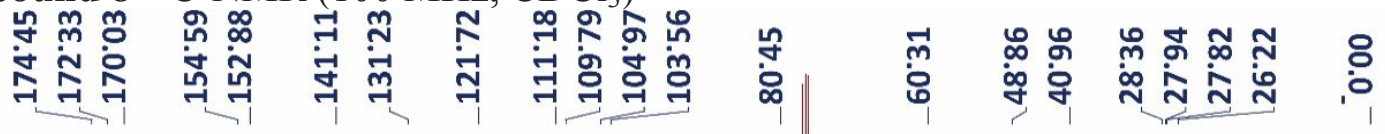

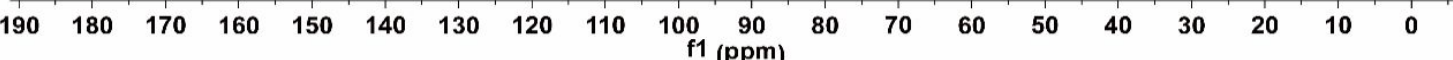


Mito-SS ${ }^{1} \mathrm{H}-\mathrm{NMR}\left(400 \mathrm{MHz}, \mathrm{CDCl}_{3}\right)$

क

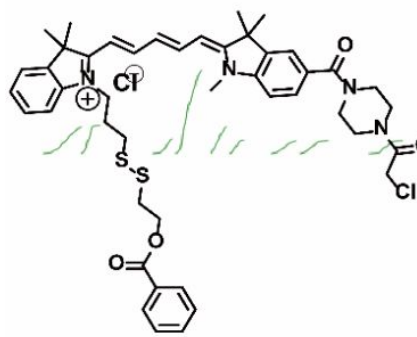

DCM

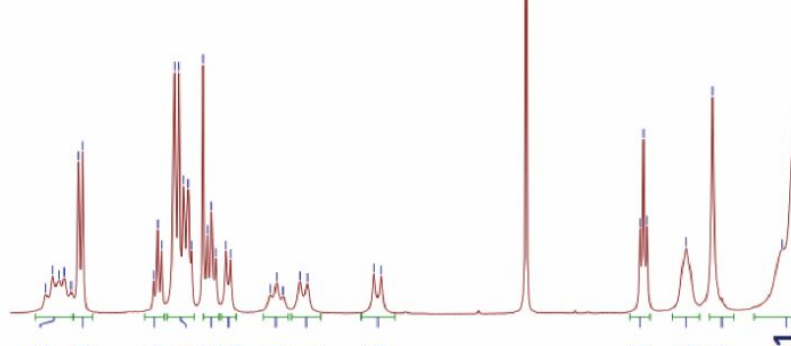

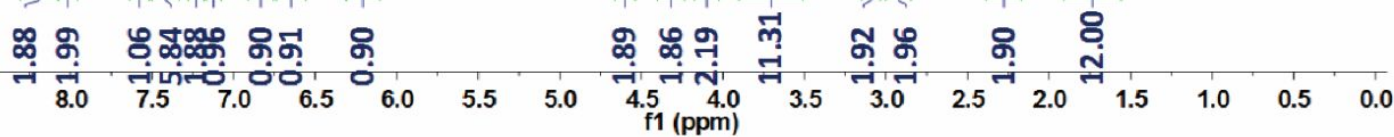

Mito-SS ${ }^{13}$ C-NMR (100 MHz, $\left.\mathrm{CDCl}_{3}\right)$

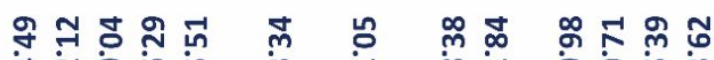

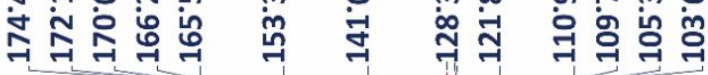

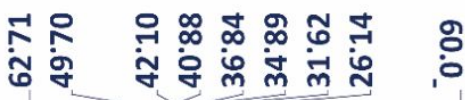

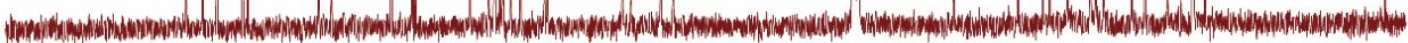

\begin{tabular}{rllllllllllllllllllllll}
\hline 200 & 190 & 180 & 170 & 160 & 150 & 140 & 130 & 120 & $110 \begin{array}{c}100 \\
\mathrm{f} 1(\mathrm{ppm})\end{array}$ & 90 & 80 & 70 & 60 & 50 & 40 & 30 & 20 & 10 & 0
\end{tabular} 
Mito-SS: High performance liquid chromatography and high-resolution mass spectra

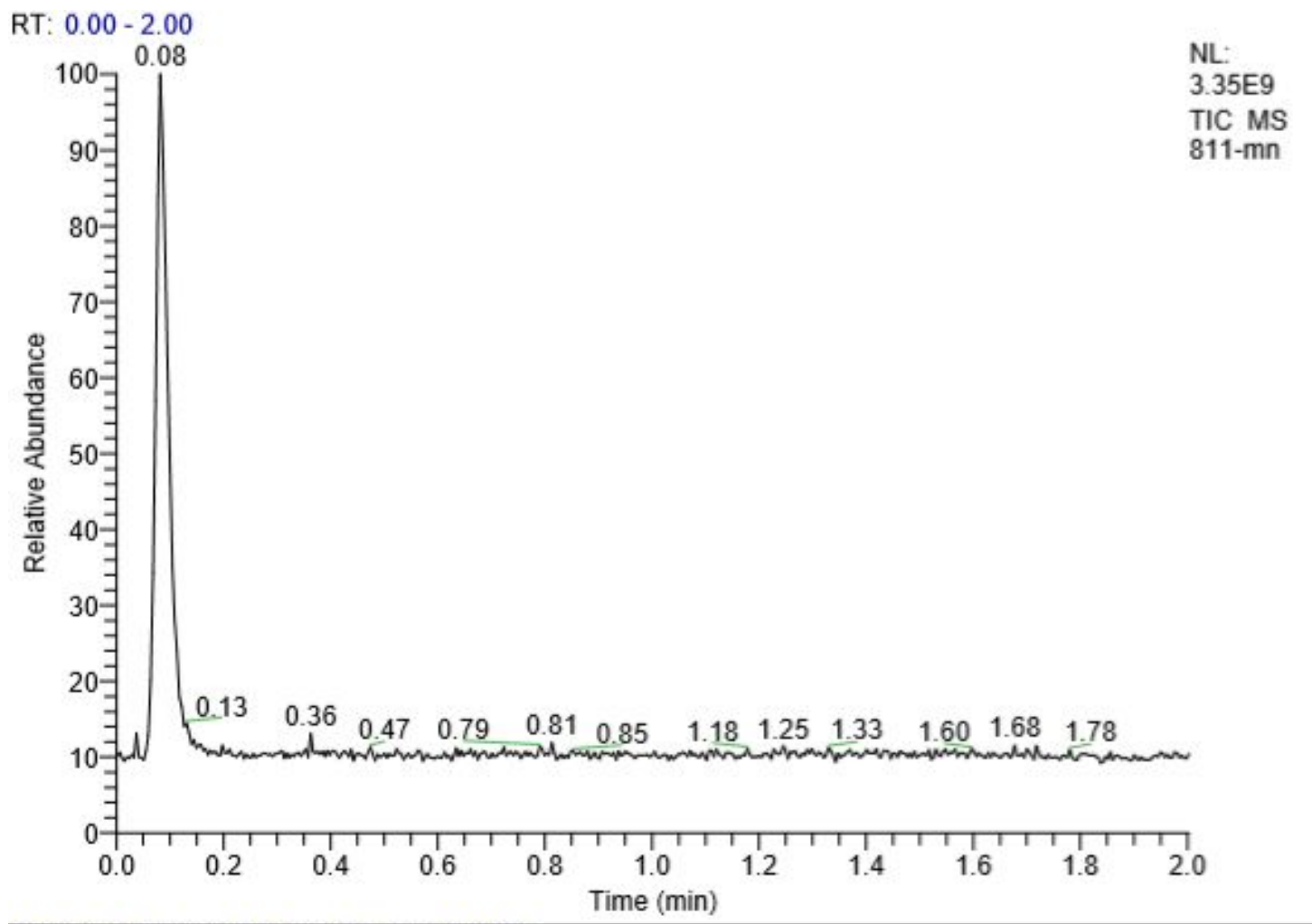

811-mn \#19 RT: 0.08 AV: 1 NL: 4.84E8

T: FTMS + p ESI Full ms [100.0000-1000.0000]

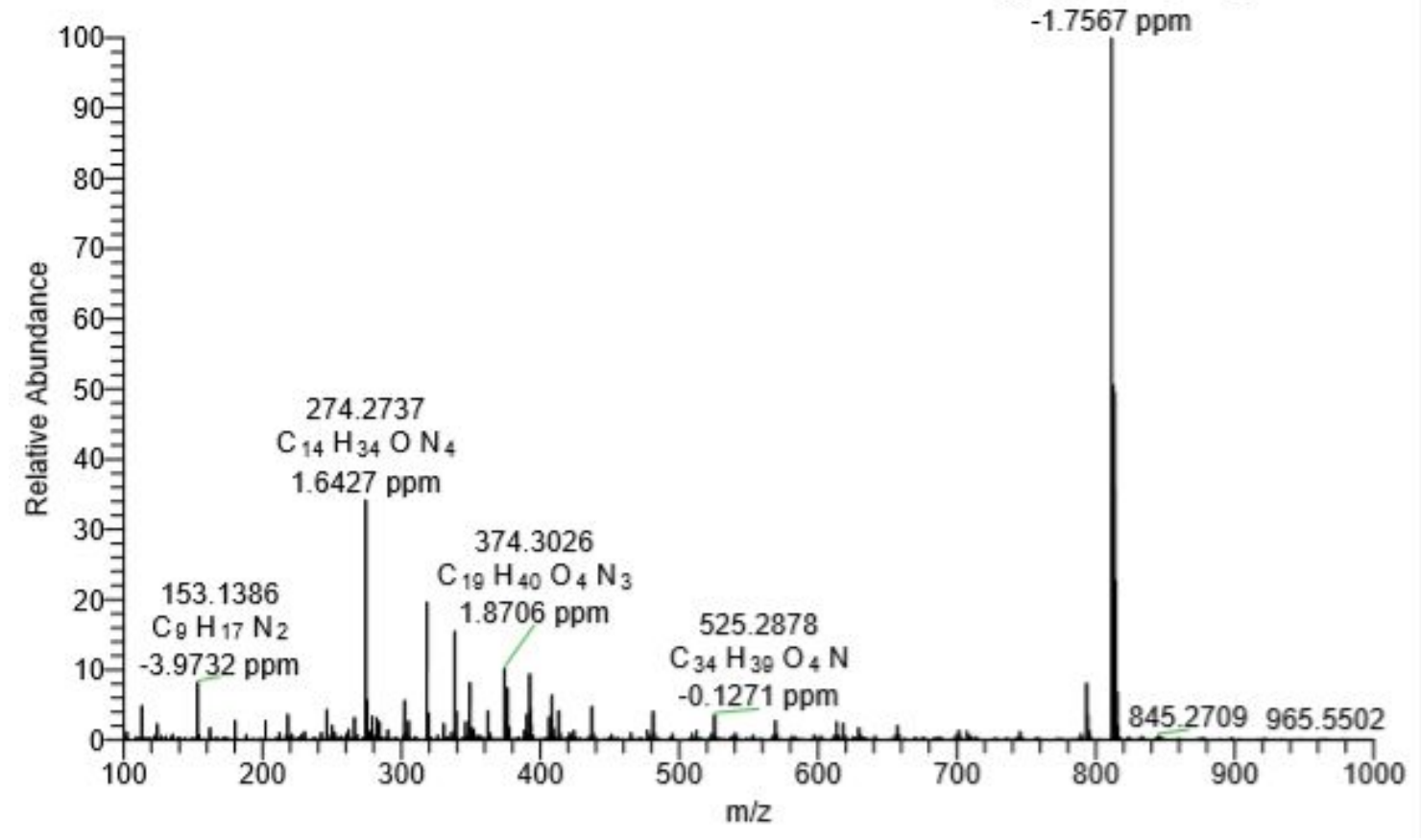




\section{Reference:}

[1] G. T. Dempsey, J. C. Vaughan, K. H. Chen, M. Bates, X. Zhuang, Nat. Methods 2011, 8, 1027

[2] L. Sheng, M. Li, S. Zhu, H. Li, G. Xi, Y. G. Li, S. X. A. Zhang, Nat. Commun. 2014, 5, 3044.

[3] J. M. Donelan, Q. Li, V. Naing, J. A. Hoffer, D. J. Weber, A. D. Kuo, Science 2008, 319, 807.

[4] J. H. Min, C. Vonesch, H. Kirshner, L. Carlini, N. Olivier, S. Holden, S. Manley, J. C. Ye, M. Unser, Sci. Rep. 2014, 4, 4577.

[5] M. Ovesny, P. Krizek, J. Borkovec, Z. K. Svindrych, G. M. Hagen, Bioinformatics 2014, 30,2389

[6] E. Block, E. V. Dikarev, R. S. Glass, J. Jin, B. Li, X. J. Li, S. Z. Zhang, J. Am. Chem. Soc. 2006, $128,14949$.

[7] D. Oushiki, H. Kojima, T. Terai, M. Arita, K. Hanaoka, Y. Urano, T. Nagano, J. Am. Chem. Soc. 2010, 132, 2795.

[8] A. Nano, A. N. Boynton, J. K. Barton, J. Am. Chem. Soc. 2017, 139, 17301. 